\title{
O INEXISTENTE DIÁLOGO ENTRE OS JULGADOS DO TRIBUNAL DE JUSTIÇA DO PARANÁ E A JURISPRUDÊNCIA DA CORTE INTERAMERICANA DE DIREITOS HUMANOS
}

\author{
THE INEXISTENT DIALOGUE BETWEEN THE JUDGMENTS OF THE PARANÁ \\ COURT OF JUSTICE AND THE JURISPRUDENCE OF THE INTER-AMERICAN COURT \\ OF HUMAN RIGHTS
}

Claudia Maria Barbosa

\begin{abstract}
Pós-Doutora pela York University, Toronto, Canadá. Graduação, mestrado e doutorado em Direito pela Universidade Federal de Santa Catarina. Professora titular da Pontifícia Universidade Católica do Paraná. Co-fundadora do Instituto Brasileiro de Administração do Sistema Judiciário-IBRAJUS. Consultora "ad hoc" do MEC. para avaliar pedidos de autorização e reconhecimento de cursos de Direito.

E-mail: claudia.mr.barbosa@gmail.com

Cinthia Obladen de Almendra Freitas
\end{abstract}

Graduação em Engenharia Civil pela Universidade Federal do Paraná, mestrado em Engenharia Elétrica e Informática Industrial pela Universidade Tecnológica Federal do Paraná e doutorado em Informática pela Pontifícia Universidade Católica do Paraná. É Professora Titular da Pontifícia Universidade Católica do Paraná - PUCPR para os cursos de Direito e Ciência da Computação. Professora Permanente do Programa de Pós-Graduação

(Mestrado/Doutorado) em Direito (PPGD).

E-mail: cinthia@ppgia.pucpr.br

Rafael Osvaldo Machado Moura

Doutorando e Mestre em Direito pelo PPGD da PUC-PR.

É Promotor de Justiça no Estado do Paraná e ex-procurador do Município de São Paulo.

E-mail: rafa.osmoura@gmail.com

Recebido em: 20/11/2017

Aprovado em: 13/12/2018

RESUMO: O status de supralegalidade atribuído pelo STF aos tratados internacionais de direitos humanos fez supor que os órgãos judiciais brasileiros os respeitariam em seus julgados. Para verificar a veracidade dessa hipótese, procedeu-se à analise empírica de acórdãos do Tribunal de Justiça do Paraná em matéria de Direitos Humanos, comparando-os à interpretação e as diretivas fixadas a respeito dessa matéria no Sistema Interamericano de Direitos Humanos, em um exercício para verificar a efetivação do necessário diálogo entre Cortes. Para tanto, definiram-se duas finalidades para a análise da amostra: a) analisar se existe compatibilidade, expressa ou tácita, entre a hermenêutica expressa nos acórdãos do TJPR em matéria de direitos humanos, com o entendimento exarado no Sistema Interamericano de Direitos Humanos; b) classificar, à luz da teoria do discurso, como os julgados da corte paranaense abordam os precedentes do SIDH. Uma amostra estatisticamente segura demonstrou que o Tribunal de Justiça do Paraná não observa os parâmetros protetivos tratados pela Corte Interamericana. Revelou, também, a inexistência de 
diálogo e, antes, a ausência de aceitação, por parte do TJPR, dos julgados da Corte IDH como fonte de Direito.

Palavras-chave: Direitos Humanos. Corte Interamericana. Tribunal de Justiça do Paraná. Diálogo.

ABSTRACT: The status of supralegality attributed by the STF to international human rights treaties meant that Brazilian judicial bodies would respect the international agreements in their judgments. To verify the true of this hypothesis, an empirical research of the judgments of the Paraná Court of Justice was made, comparing them with the interpretation and directives established by the Inter-American Court of Human Rights, in order to verify the effectiveness of the necessary dialogue between courts. To achieve this goal two specific objectives have been defined as follows: a) to examine whether the hermeneutics of the Inter-American system has been, at least implicitly, observed by the Paraná Court of Justice; and b) in the light of theories of discourse analysis, this work will classify current judgments, either expressed or implied, of the precedents of the inter-American system by the Paraná judges in decisions involving human rights. The search reveals that the state court does not accept the protective parameters outlined by the Inter-American Court.

Keywords: Human Rights. Inter-American Court. Paraná Court of Justice. Dialogue.

SUMÁRIO: Introdução; 1 Princípios metodológicos da pesquisa empírica; 1.1 Definição da 1amostra; 1.2 Análise da amostra; 2 Análise das decisões do Tribunal de Justiça do Paraná que enfrentam temas debatidos na Corte IDH; 2.1 Dados encontrados em cada um dos seis temas debatidos na Corte IDH; 3 O monólogo do TJPR; Conclusão; Referências.

\section{INTRODUÇÃO}

A inserção do Brasil no Sistema Interamericano de Direitos Humanos - SIDH - tem sido pauta dos últimos governos brasileiros e é um caminho seguro para aproximar o país de outros Estados democráticos que protegem de forma mais efetiva o Direito Internacional dos Direitos Humanos - DIDH. A justiça brasileira tem um importante papel na defesa e proteção dos direitos humanos, de maneira que o diálogo entre cortes internacional e doméstica é não apenas desejável, mas condição necessária, embora não suficiente, para promover a sua defesa no Brasil. Apesar de ser imprescindível, a pesquisa procura denunciar a ausência desse diálogo no processo de tomada de decisões em matéria de direitos humanos no Tribunal de Justiça do Paraná - TJPR - e demonstrar a ausência de impacto de precedentes e normativas estabelecidos pelo SIDH nos julgamentos desse órgão superior de Justiça paranaense.

O Estado brasileiro aderiu aos documentos internacionais vinculantes do Sistema Interamericano, bem como se submeteu à jurisdição da Corte Interamericana - Corte IDH. Para que esta tenha competência jurisdicional, faz-se necessário que o país aceite a função contenciosa do órgão, com manifestação de vontade expressa nesse sentido, a ser depositada na sede da Organização dos Estados Americanos, em conformidade com o que estabelece o artigo 62 da Convenção Americana. O Brasil, embora tenha adotado - ratificado - a Convenção Americana em 1992 e, por consectário legal, se sujeitado ao monitoramento pela Comissão Interamericana CIDH - , apenas permitiu ser jurisdicionado pela Corte IDH em dezembro de 1998, por intermédio do Decreto Legislativo n. 88/1998.

A sentença da lavra da Corte IDH, nos dizeres da Convenção Americana, notadamente do artigo 68, 1 e 2, deve ser executada no plano interno como se produzida pelo direito interno. Daí 
ser relevante que o sistema brasileiro de Justiça observe os precedentes emanados por aquela Corte, estabelecendo verdadeiro diálogo de cortes.

Para conferir o possível diálogo, pesquisaram-se temas comuns à Corte Interamericana de Direitos Humanos - CIDH - e ao TJPR. A eleição dos temas decididos pela Corte IDH se fez a partir dos cadernos oficiais de jurisprudência da Corte IDH. Por me destes resumos autênticos de jurisprudência (OAE, 2015), foi possível chegar-se aos assuntos tratados com maior assiduidade pela Corte IDH, tais como questões relativas ao direito das crianças e adolescentes, ao direito das mulheres, ao controle de convencionalidade, ao direito à liberdade de expressão, ao direito à liberdade pessoal e ao deslocamento forçado. A partir da leitura de cada um dos cadernos temáticos de jurisprudência da Corte IDH, os autores produziram breves enunciados, sintetizando alguns dos principais entendimentos do Órgão jurisdicional internacional.

A eleição dos temas e julgados do TJPR fez-se por meio da pesquisa jurisprudencial disponível no sítio do órgão.

Identificados os temas comuns à Corte IDH e ao TJPR, selecionaram-se os julgados paranaenses a serem cotejados com os entendimentos oriundos do Corte IDH, buscando estabelecer os vínculos entre a jurisprudência emanada por ambos os Órgãos jurisdicionais, o que se fez de acordo com os procedimentos explicados nos itens à frente.

\section{PRINCÍPIOS METODOLÓGICOS DA PESQUISA EMPÍRICA}

Pesquisas empíricas na área jurídica ainda são escassas no Brasil, razão pela qual se optou por descrever procedimentos que, se à primeira vista devem ser familiares a pesquisadores de outras áreas, ainda são novidades no plano jurídico. Pesquisas que trabalham modelos empíricos precisam revelar muito sobre o "processo pelo qual geraram e observaram seus dados - todo o processo, do momento em que o mundo gerou o fenômeno de interesse até o momento em que os dados estavam em sua posse e foram considerados definitivos" (EPSTEIN, 2013, p. 42).

Assim, importa que se explique como os autores chegaram à "jurisprudência relevante e qual foi precisamente a população da qual extraíram sua amostra; como os autores selecionaram seus casos e quantos eles leram" (EPSTEIN, 2013, p. 52). Nessa esteira, o material objeto deste trabalho foi selecionado por uma decisão não arbitrária e que pode ser revelada pelos autores, com a finalidade de conceder aos leitores do trabalho meios para aferir a qualidade do levantamento dos dados e das inferências respectivas.

Neste giro, rememore-se que a presente pesquisa trabalha, em síntese, com comparativos entre a jurisprudência do SIDH e do TJPR. Dito de outro modo: na esteira das lições de Lee Epstein e Gary King, visa-se apurar se a variável causal principal - no caso concreto, a existência de fundamentos jurídicos para que o poder judiciário doméstico acate as decisões da Corte IDH causou um resultado específico. Após verificar a variável dependente - nesta pesquisa, a saber, a taxa de repercussão da jurisprudência interamericana na justiça estadual.

\subsection{Definição da amostra}

Para a pesquisa empírica partiu-se da identificação do conjunto de acórdãos da lavra do TJPR, obtido a partir da pesquisa de jurisprudência no sítio virtual da Corte paranaense, que, em 15 de novembro de 2015, tinha armazenadas precisamente 2.352 .595 (dois milhões, trezentos e cinquenta e dois mil e quinhentos e noventa e cinco) decisões (BRASIL, 2015).

Do universo destes mais de 2.000.000 de decisões, selecionou-se primeiramente aquelas proferidas após 03 de dezembro de 2008, data da paradigmática decisão do Supremo Tribunal 
Federal que atribuiu o status de "supralegalidade" às convenções internacionais de direitos humanos recepcionadas pelo Brasil sem o rito das emendas constitucionais. Tais acórdãos constituem a base mais importante da pesquisa quer pela pertinência temática - enfoque em decisões que envolvem os temas debatidos do SIDH, quer pela relevância atual dos tratados internacionais sobre direitos humanos, entre os quais a Convenção Americana de Direitos Humanos - CADH.

Desse conjunto, extraiu-se amostra estatisticamente representativa do universo das decisões disponíveis para ser examinada em toda sua extensão. A amostra é necessária porque a análise do universo disponível é inviável.

Universo são os elementos totais a serem verificados. Amostra, por outro lado, constituise em um determinado número reduzido de itens, analisados para verificar determinada característica do todo. Amostra é, portanto, um subconjunto do conjunto total, que é o universo (RICHARDSON, 1999, p. 158).

A amostra, no presente caso, foi delineada por intermédio de uma revisão sistemática, método de análise científica pelo qual determinados pontos substanciais são avaliados e interpretados, considerando todas as pesquisas disponíveis e relevantes quanto a um tópico de interesse (KITCHENHAM, 2004, p. 2) ${ }^{1}$. Tal revisão objetiva apresentar correta interpretação de tópico de pesquisa, valendo-se de confiável e rigorosa auditoria metodológica.

Optou-se pela revisão sistemática para obter-se melhor amostragem de pesquisa, de modo a abranger decisões de ambas as Cortes, Interamericana e do Estado do Paraná, contendo questões tais como direito da mulher e prisão preventiva.

Após leitura da jurisprudência da Corte IDH inscrita em suas publicações oficiais (cadernos de jurisprudência), recortaram-se os 06 (seis) principais temas tratados pelo Órgão interamericano que também são objeto dos julgados da Justiça Estadual brasileira, bem como algumas das suas mais relevantes orientações interpretativas em cada um dos temas.

Explica-se, neste giro, como se chegou à jurisprudência da Corte IDH, ou seja, como se pavimentou o caminho para a coerente e lógica busca das principais teses defendidas pela Corte IDH, que apresentam pertinência com as manifestações do judiciário estadual, para se empregarem como parâmetros de comparação neste trabalho.

Por primeiro, para evitar que se alongasse excessivamente a vertente pesquisa, não se perscrutaram detalhadamente todas as quase trezentas decisões contenciosas da Corte IDH. Dado que tal trabalho de descrição e organização do conteúdo intelectual dos julgados da Corte IDH já fora levado a cabo pelo próprio Órgão jurisdicional interamericano, optou-se por valer-se do material já produzido, o qual contém resumos dos mais relevantes entendimentos jurisprudenciais do órgão (OEA, 2015).

Optou-se, como já antecipado, por valer-se apenas do conteúdo a envolver matérias típicas e diretas da justiça estadual e que apresentem alguma relevância no contexto brasileiro. Esses critérios acabaram por excluir os temas da pena de morte, migrantes, migração, refúgio e apátridas, anistia e direito à verdade e direitos dos povos indígenas, tendo-se mantido os demais, quais sejam, deslocamento forçado, direito das mulheres; direitos das crianças e adolescentes; controle de convencionalidade; direito à liberdade pessoal; e direito à liberdade de expressão.

Alguns dos temas selecionados, pela sua complexidade e diversidade, foram subdivididos em subgêneros. Assim, o direito das mulheres cindiu-se em discriminação baseada em gênero,

\footnotetext{
${ }^{1}$ Texto original: "A systematic literature review is a means of identifying, evaluating and interpreting all available research relevant to a particular research question, or topic area, or phenomenon of interest. Individual studies contributing to a systematic review are called primary studies; a systematic review is a form a secondary study".
} 
corpo e maternidade e violência de gênero; o direito das crianças e adolescentes foi desmembrado em princípio do interesse superior, direito à vida, direito à integridade pessoal e direito à liberdade pessoal; o direito à liberdade de expressão ficou subdividido em liberdade de expressão em sentido estrito, direito de resposta e direito de acesso à informação.

Em sequência, por intermédio dos Cadernos de Jurisprudência, emitidos pela própria Corte IDH, formularam-se sínteses do conteúdo decisório, elaborando-se enunciados para cada um dos seis temas. E a partir de cada um dos temas e subtemas assinalados, confeccionaram-se argumentos de pesquisa (palavras-chave) para a coleta da amostra final.

No tocante ao primeiro dos seis assuntos - deslocamento forçado -, foram delineados sete enunciados, de acordo com a Tabela 1.

\section{Tabela 1: Deslocamento forçado - jurisprudência da Corte IDH}

a. $\quad$ Deslocamento forçado significa compelir alguém a abandonar sua residência habitual. Os deslocados internos são as pessoas ou grupos de pessoas que têm sido forçadas ou obrigadas a escapar ou fugir de seu lar ou de seu lugar de residência habitual, em particular como resultado ou para evitar os efeitos de um conflito armado, de violência generalizada, desastres naturais e de outras violações de direitos humanos.

b. Efeitos: perda de terra, marginalização, graves repercussões psicológicas, desemprego, empobrecimento e deterioração das condições de vida, incremento das enfermidades e da mortalidade, além da perda de acesso à propriedade comum, da insegurança alimentar e da desarticulação social.

c. As pessoas deslocadas se encontram em situação de acentuada vulnerabilidade, o que gera obrigações ao Estado.

d. Interpretação evolutiva do art. 22 da $\mathrm{CADH}$, de modo que o direito à residência é ferido tanto quando há restrições legais a ele, como também quando há situações de fato que impedem o seu exercício.

e. Deslocamento forçado agride os direitos à integridade pessoal (art. 5), à proteção da família e não intervenção ilegítima do Estado (art. 17), a vida privada (art. 11), propriedade (art. 21).

f. No contexto de violações a tal direito, verifica-se vulnerabilidade acentuada de mulheres, crianças e idosos.

g. Medidas de reparação ditadas no contexto da população deslocada: I - presunção de dano moral; II - alteração das condições de existência como critério para ordenar a reparação do dano imaterial; III - programas de vivenda; IV - programas de saúde.

Fonte: Adaptado de (BRASIL, 2015).

Sobre o tema direito de gênero, outros seis enunciados foram confeccionados, como mostrado na Tabela 2.

\section{Tabela 2: Direito das mulheres - jurisprudência da Corte IDH}

a. Nem toda a violação de um direito humano cometida em prejuízo de uma mulher implica necessariamente uma violação às disposições da Convenção de Belém do Pará. Para tanto, há que se demonstrar em que sentido as agressões foram especialmente dirigidas contra as mulheres, bem como se estas se converteram em um maior alvo de ataques por sua condição de mulher. 
b. O estereótipo de gênero se refere a uma preconcepção de atributos ou características ou papéis que são ou deveriam ser executados por homens e mulheres respectivamente. Estereótipos de gênero são incompatíveis com o DIDH e os tribunais internos devem tomar medidas para erradicá-los.

c. Os Estados têm a obrigação de emprestar atenção especial às mulheres por razões de maternidade, o que implica, entre outras medidas, assegurar que se levem a cabo, em estabelecimentos penais, visitas entre mães e filhos, bem como atendimento especial nos períodos menstruais ou de gravidez.

d. A infertilidade pode afetar homens e mulheres. Todavia, a utilização das tecnologias de reprodução assistida se relaciona especialmente com o corpo das mulheres, de modo que a proibição da indução à ovulação tem um impacto desproporcional sobre elas. Os direitos à saúde das mulheres devem ser considerados em perspectiva dos fatores biológicos e a de sua função reprodutiva.

e. A violência sexual é um tipo particular de agressão que, no geral, se caracteriza por produzir-se em ausência de outras pessoas para além da vítima e do agressor. Dada a natureza desta forma de violência, não se pode esperar a existência de provas gráficas ou documentais e, portanto, a declaração da vítima constitui uma prova fundamental sobre o feito.

f. Durante a investigação e julgamento, o Estado deve assegurar o pleno acesso e a capacidade de atuar da vítima em todas as suas etapas. Em um caso como o presente no qual a vítima é mulher, participando das diligências do caso para o qual deve assegurar-lhe a provisão de apoio desde uma perspectiva de gênero.

Fonte: Adaptado de (BRASIL, 2015).

Em relação ao terceiro tema, direito da criança e adolescente, mais enunciados foram elaborados e, portanto, apresenta-se a Tabela 3.

\section{Tabela 3: Direito da criança e adolescente - jurisprudência da Corte IDH}

a. É direito da criança, decorrente do princípio do interesse superior, ser ouvida, expressando de maneira independente suas opiniões, em procedimentos em que é interessada, o que deve ser feito progressivamente de acordo com o grau de desenvolvimento biológico da infante.

b. O interesse superior da criança e do adolescente assegura, especialmente em casos em que estes hajam sido vítimas de delitos como abusos sexuais ou outras formas de maltrato, seu direito a ser escutado se exerça garantindo sua plena proteção, devendo os servidores públicos apresentarem-se capacitados para atendê-los e as salas de entrevistas representarem um entorno seguro e não intimidatório, hostil, insensível ou inadequado. Ainda, as crianças e adolescentes não devem ser interrogados em mais ocasiões que as necessárias para evitar, na medida do possível, a revitimização ou um impacto traumático na criança.

c. O interesse superior da criança, em casos de guarda, deve ser analisado a partir da avaliação de comportamentos específicos dos pais e seu impacto negativo ao bemestar e desenvolvimento da criança. Portanto, não podem ser admitidas as especulações, presunções, estereótipos ou considerações generalizadas sobre características pessoais dos pais ou preferencias culturais a respeito de certos conceitos tradicionais de família. 


\section{Tabela 3: Direito da criança e adolescente - jurisprudência da Corte IDH}

d. Em essência, o direito à vida compreende não apenas não ser privado dela arbitrariamente, como também o direito a que não se lhe impeça o acesso às condições que lhe permitam uma existência digna, de modo a garantir a máxima medida do desenvolvimento das crianças, o que abarca os aspectos físico, mental, espiritual, psicológico e social. Os Estados detêm a obrigação de prover a criação de condições que se requeiram para que não se produzam violações a esse direito básico, impedindo que seus agentes atentem contra eles.

e. Para salvaguardar o direito à integridade pessoal dos adolescentes detidos, é indispensável que sejam separados dos adultos encarcerados. Além disso, as pessoas encarregadas dos centros de detenção dos adolescentes infratores ou processados devem estar devidamente capacitadas para o desempenho de seus encargos. Por fim, têm direito a se comunicarem com terceiros que lhes deem assistência e defesa, além de que devem os agentes estatais comunicarem imediatamente a detenção do menor aos responsáveis pelos adolescentes.

f. Dentro dos estabelecimentos de detenção para adolescentes deve existir, no mínimo, uma separação por categorias de idade, natureza da infração cometida e entre jovens ainda processados e aqueles já condenados, de modo que os internos pertencentes a categorias diversas deverão ser alojados em diferentes setores dentro do estabelecimento. $\mathrm{O}$ critério principal para separar os direitos grupos de menores com liberdade restrita deverá ser a prestação do tipo de assistência que melhor se adapte às necessidades concretas dos interessados e à proteção de seu bem-estar e integridade física, mental e moral.

g. A privação de liberdade de menores de idade deve ser excepcional e a mais breve possível, aplicando-se com maior rigor os requisitos para a prisão preventiva de adultos, além de que se deve priorizar a aplicação de medidas substitutivas à restrição de liberdade.

Fonte: Adaptado de (BRASIL, 2015).

No item controle de convencionalidade, formularam-se os excertos descritos na

Tabela 4.

\section{Tabela 4: Controle de convencionalidade - jurisprudência da Corte IDH}

a. Conceito do controle de constitucionalidade: no caso concreto, os juízos devem verificar a compatibilidade das normas e demais práticas internas com a CADH e a jurisprudência da Corte IDH.

b. De acordo com a Convenção de Viena sobre Tratados, o Brasil deve cumprir de boafé suas obrigações diante da $\mathrm{CADH}$, não podendo invocar disposições do direito interno como justificativa para eventual inobservância de seus compromissos internacionais.

c. O controle de constitucionalidade há de ser realizado de ofício pelos juízes de primeiro contato.

d. Não só juízes, mas órgãos vinculados ao sistema de Justiça se obrigam a levar a efeito o controle.

e. A obrigação se estende a outros tratados, além da CADH.

f. O parâmetro do controle se estende às opiniões consultivas da Corte IDH. 
g. Carrega obrigação de adequar legislação aos parâmetros internacionais, inclusive declarando-se a nulidade de eventual lei anticonvencional.

h. Controle de convencionalidade e eficácia interpretativa: interpretação conforme a CADH pode ser manejada nos casos em que couber.

i. A jurisprudência da Corte IDH serve de parâmetro de controle, gerando coisa julgada internacional.

Fonte: Adaptado de (BRASIL, 2015).

No quinto tema da pesquisa, direito à liberdade pessoal, foram considerados os pontos apresentados na Tabela 5.

\section{Tabela 5: Direito à liberdade pessoal - jurisprudência da Corte IDH}

a. A decisão de prisão deve ser devidamente fundamentada, observando os princípios da legalidade, necessidade e proporcionalidade.

b. Há que se indicar provas suficientes que permitam presumir a culpabilidade do indivíduo submetida a um processo.

c. A prisão preventiva exige a indicação de que é estritamente necessária para assegurar que o investigado não impeça o desenvolvimento eficiente das investigações e, tampouco, se furte à justiça. A privação da liberdade não pode ser fundamentada com base na finalidade preventiva geral ou especial atribuída à pena.

d. A privação da liberdade deve estar sujeita à revisão periódica, não devendo ser estendida quando não subsistirem os seus motivos. As autoridades nacionais são responsáveis por avaliar a pertinência da manutenção de medidas cautelares fixadas, em conformidade com a própria lei. Ao realizar tal tarefa, as autoridades devem apresentar fundamentos pelos quais se mantém a restrição de liberdade, de acordo com o que prevê o artigo 7.3 da Convenção Americana de Direitos Humanos. De acordo com a Corte Interamericana de Direitos Humanos, o juiz, para realizar a avaliação periódica da manutenção dos requisitos da segregação cautelar, não deve esperar a absolvição do detento, devendo avaliar os fundamentos da medida, a sua necessidade e proporcionalidade, bem como se o período da prisão excedeu os limites impostos pela lei e pela razão. Sempre que a prisão não satisfizer tais condições, deve o juiz, sem prejuízo da continuidade do processo, conceder-lhe a liberdade.

e. O direito de a pessoa presa ou detida estar informada das razões da sua prisão e notificada, sem demora, das acusações formuladas contra si, está consagrado no artigo $7^{\circ}$, item 4, da Convenção Americana de Direitos Humanos, que não faz distinção da prisão decretada por ordem do Tribunal ou em flagrante. A informação sobre os motivos e razões da prisão devem, necessariamente, envolver: a própria detenção; a pessoa detida compreender claramente que está sendo presa; o agente que realizar a prisão informar, em linguagem simples, livre de tecnicismos, os fatos e fundamentos que baseiam a detenção. A simples menção do dispositivo legal não satisfaz o previsto no artigo $7^{\circ}$, item 4, da Convenção Americana de Direitos Humanos.

Fonte: Adaptado de (BRASIL, 2015). 
Por fim, no que concerne à liberdade de expressão, colheram-se os seguintes enunciados da jurisprudência da Corte IDH, conforme Tabela 6.

\section{Tabela 6: Direito à liberdade de expressão - jurisprudência da Corte IDH}

a. Reconhece-se a dupla dimensão do direito: uma individual, pertencente a cada pessoa, significando a possibilidade de falar ou escrever, compreendendo, ademais, a utilização de qualquer meio apropriado para difundir o pensamento; e a outra social, sendo um direito da sociedade ao intercâmbio de ideias e informações e para a comunicação de massa.

b. Proibição de censura prévia, por qualquer um dos poderes. A exceção são os espetáculos públicos que podem ser submetidos por lei à censura prévia com o exclusivo objeto de regular o acesso a eles para a proteção moral da infância e adolescência.

c. O abuso do direito à liberdade de expressão só pode ser restringido por intermédio de responsabilizações ulteriores à expressão ou difusão da informação. Há que se fazer um teste tripartite para controlar a legitimidade das limitações à liberdade de expressão: (1) a limitação deve ter sido definida em forma precisa e clara e por intermédio de lei formal e material; (2) a limitação deve estar orientada a atingir objetivos autorizados pela Convenção Americana; e (3) a limitação deve ser necessária em uma sociedade democrática, estritamente adequada e idônea ao objetivo que pretende lograr.

d. Devem gozar de uma proteção especial as manifestações relativas à conduta de servidores públicos, de políticos e de particulares, que exercem funções públicas ou que desenvolvem atividades submetidas ao escrutínio público.

e. Diante de abuso do exercício do direito à liberdade de expressão, deve-se acudir às medidas menos restritivas à liberdade de expressão para reparar o prejuízo: em primeiro lugar, ao direito de retificação ou resposta; se não bastar, então se demonstrará a existência de um dano grave, causado com a intenção de causar dano e com o evidente desprezo à verdade, poder-se-á acudir-se a mecanismos de responsabilidade civil que cumpram com as condições estritas derivadas do artigo 13.2 da Convenção.

f. Para que se reparem civilmente os prejuízos, há alguns outros requisitos a serem observados: (a) a aplicação do "standart" da "real malícia", demonstrando-se que quem se expressou o fez com plena intenção de causar um dano e conhecendo que estava difundindo informações falsas ou com um evidente desprezo pela verdade dos fatos; (b) ônus da prova - nos casos em que se pretenda evidenciar a responsabilidade de quem haja abusado de seu direito à liberdade de expressão, quem alega deve suportar o ônus de demostrar que as expressões pertinentes eram falsas e causaram efetivamente o dano alegado; (c) ainda que não provada a veracidade do que se afirmou, é possível não aplicar sanções penais ou civis, desde que existam razões suficientes para justificar a formulação de tais afirmações, sempre que digam respeito ao interesse público.

g. O direito à liberdade de expressão compreende o direito a buscar e receber informação pública. Os estados devem garantir que toda pessoa possa aceder à dita informação. Só podem negar informações de maneira fundamentada e em razão de 


\section{Tabela 6: Direito à liberdade de expressão - jurisprudência da Corte IDH}

fins legítimos, devendo habilitar vias para que as pessoas possam pedir informações sem necessidade de justificar nenhum interesse especial. $\mathrm{O}$ acesso à informação pode ser restringido somente nos casos previstos em lei e unicamente com a finalidade de respeitar direitos ou a reputação de terceiros, proteger a seguridade nacional, à ordem pública ou a saúde e moral públicas, sempre que a restrição seja necessária em uma sociedade democrática.

h. Incompatibilidade fundamental entre as leis de desacato e a Convenção Americana, por contrariarem a liberdade de expressão prevista no artigo 13 da CADH.

Fonte: Adaptado de (BRASIL, 2015).

À luz de tais enunciados dos parâmetros protetivos do SIDH, colhidos a partir do Caderno de Jurisprudência da Corte IDH, passou-se ao passo seguinte, qual seja, identificar por meio do uso de argumentos de pesquisa (palavras-chave) os julgados da Corte estadual que seriam confrontados à jurisprudência do SIDH selecionada. Portanto, na base de dados do TJPR, coletou-se uma amostragem de julgados para análise.

Na pesquisa, utilizou-se a técnica do distinguishing ${ }^{2}$ (MARINONI, 2013), a permitir a apuração dos casos do TJPR sob análise, para a adoção, ou não, do precedente oriundo, no caso, da Corte IDH. Optou-se por valer-se de tal procedimento comparativo de jurisprudências, nada obstante as maiores dificuldades - conforme aponta Marinoni-em aplicarem-se precedentes numa dimensão supranacional, tendo em vista a maior probabilidade de deparar-se com diferenças políticas e sociais entre os diversos países, muitas vezes a impossibilitar a definição de uma regulação igualmente legítima para todos.

É interessante enfatizar que a busca por palavras-chave - também conhecidas como argumentos de pesquisa - combinou duas diferentes formas de busca: a primeira de forma livre, buscando-se palavras ou isoladas ou conectadas pela letra "e", encontrando o sistema de decisões que continham tais termos em qualquer ordem, mesmo que trechos distantes uma da outra; já em um segundo tipo de pesquisa, formulada com termos exatos, valeu-se de palavras-chave delimitadas por aspas duplas, o que fez com que o sistema de buscas apenas separasse as decisões que contivessem as palavras exatamente na ordem que foram escritas pelos autores da pesquisa.

Assim, os dados brutos colhidos do TJPR, com todos os argumentos de pesquisa, totalizaram 63.636 decisões, componentes da população ou universo total dos itens de interesse.

A definição dos dados até aqui se obteve a partir da adoção de critérios e características estabelecidos à luz dos seis assuntos já objeto de decisões da Corte IDH. Tal amostra, portanto, classifica-se como sendo do tipo intencional ou de seleção racional, não probabilística, portanto (RICHARDSON, 1999, p. 161). Isto significa que as unidades amostrais não são aleatórias, não sendo possível estabelecer uma margem de erro e níveis de confiança, mas informam como é o universo.

Porém, nesta quadra - em que já se chegou a enunciados de jurisprudência da Corte IDH e às mais de sessenta e três mil decisões do TJPR, para serem comparados -, ainda não se está a falar da amostra definitiva, visto que se produziu até aqui apenas parte da população ou do universo das decisões interessantes, mostrando-se necessária - sobretudo em casos em que o número inicial de amostras se revela muito extenso, como o do presente trabalho - nova delimitação.

\footnotetext{
${ }^{2}$ Método de cotejamento entre o caso em análise e o precedente. Como a aplicação do precedente não é automática, sendo necessária a interpretação, há que se avaliar se o caso em exame é substancialmente similar ao precedente invocado.
} 
A Tabela 7 apresenta o resumo de tais dados brutos, por assuntos - seis no total - e subitens.

Tabela 7: Número de julgados encontrados e itens e subitens

\begin{tabular}{|c|c|}
\hline Temas da Corte IDH & Total \\
\hline 1. Deslocamento forçado & 203 \\
\hline 2.1 Discriminação baseada em gênero & 1916 \\
\hline 2.2 Corpo e maternidade & 302 \\
\hline 2.3 violência de gênero & 648 \\
\hline $\begin{array}{l}3.1 \text { Interesse superior }- \text { criança e } \\
\text { adolescente }\end{array}$ & 7152 \\
\hline 3.2 direito à vida - criança e adolescente & 3451 \\
\hline $\begin{array}{l}3.3 \text { direito à integridade pessoal - criança } \\
\text { e adolescente }\end{array}$ & 94 \\
\hline $\begin{array}{l}3.4 \text { direito à liberdade pessoal - criança e } \\
\text { adolescente }\end{array}$ & 107 \\
\hline 4. Controle de convencionalidade & 13 \\
\hline 5. Direito à liberdade pessoal & 44067 \\
\hline 6.1 Liberdade de expressão & 1462 \\
\hline 6.2 Direito de resposta & 698 \\
\hline 6.3 Direito de acesso à informação & 3523 \\
\hline Total Geral & 63636 \\
\hline
\end{tabular}

Fonte: Adaptado de (BRASIL, 2015).

Diante da quantidade elevada de acórdãos encontrada em cada um dos argumentos de pesquisa utilizados, chegou-se a uma primeira amostra, com a qual seria bastante difícil trabalharse. Assim, submeterem-se tais dados a uma análise estatística descritiva ${ }^{3}$, mediante medidas de posição, medidas de dispersão, análise de "outliers" e análise de assimetria (KAZMIER, 1982), chegando-se a uma conclusão sobre o tamanho ideal das amostras (SPIEGEL, 1978, p. 5-6). A análise determinou que, para cada um dos subitens a serem analisados, poder-se-ia compor amostras de tamanho igual a 30 (trinta) decisões, escolhidas aleatoriamente e proporcionalmente a cada argumento de pesquisa com resultado diferente de zero. Este critério de amostragem enquadra-se na teoria de pequenas amostras quando $n<30$, sendo $n$ o tamanho da amostra, bem como foi aplicado, visto que os resultados caracterizam-se como heterogêneos ${ }^{4}$ (coeficiente de

\footnotetext{
${ }^{3}$ A Estatística Descritiva inclui as técnicas que dizem respeito à sintetização e à descrição dos dados numéricos (KAZMIER, 1982, p. 1). São exemplos de técnicas: a) medidas de posição: média, mediana e moda (KAZMIER, 1982, p. 29-44); b) medidas de dispersão: desvio padrão e variância (KAZMIER, 1982, p. 45-51); c) assimetria: permite conhecer as diferenças entre os valores da média, da mediana e da moda (KAZMIER, 1982, p. 33,52-53). A análise de "outliers" permite descartar dados "mentirosos" que possam ter sido coletados erroneamente ou que não representam o universo e, portanto, não poderão compor a amostra. São "outliers" os dados que se diferenciam drasticamente de todos os demais, caracterizando-se como "pontos fora da curva” (KAZMIER, 1982, p. 33,52-53).

${ }^{4} \mathrm{O}$ coeficiente de variação indica a magnitude relativa entre o desvio padrão e a média e por ser uma medida relativa deve ser expresso em \% (KAZMIER, 1982, p. 52). Quanto menor for o valor do coeficiente de variação, mais homogêneos serão os dados, ou seja, menor será a dispersão em torno da média. De um modo geral, se coeficiente de
} 
variação > 20\%). Além disto, a média e a mediana apresentam valores muito distintos, indicando assimetria forte ${ }^{5}$, visto que valores, de média e mediana, muito próximos é uma indicação que o conjunto de dados é razoavelmente simétrico em relação à posição central que é a média. Fato que não ocorre com os dados ora analisados. A análise estatística revelou que os dados apresentam assimetria forte e positiva (à direita) com $|\mathrm{SK}|>0,50$.

De posse da construção estatística da amostra, em vez de perscrutarem-se todas as mais de sessenta e três mil decisões, com base na estatística descritiva, foram analisados $373^{6}$ julgados, sendo esta amostra representativa e significativa estatisticamente, portanto, confiável para ser um recorte do universo de acórdãos do TJ sobre os treze pequenos temas analisados, de um total de seis grandes temas. A metodologia empregada evitou que se realizasse uma amostragem aleatória, ou seja, todos os indivíduos do universo precisam ter probabilidade não-nula de serem selecionados, o que é um requesito exigente, o qual dificulta a formação da amostragem ou pode viciar a amostra. Frise-se que se trabalhou com a análise de 30 (teoria das pequenas amostras) decisões em cada um dos 13 subitens, a serem divididas proporcionalmente, à luz do percentual do número de julgados encontrados por intermédio de cada um dos argumentos. Assim, foram a análise de 30 decisões por subitem não é coincidência, mas é uma garantia estatisticamente aceita e comprovada no meio técnico.

\subsection{Análise da amostra}

Como visto, as decisões do TJPR foram cotejadas com a jurisprudência do SIDH, buscando-se averiguar se existe harmonia entre as manifestações de ambos os sistemas - o doméstico paranaense e o interamericano.

Neste passo, para classificar como se deu a interação entre as jurisprudências regional e paranaense, a intenção era a de utilizar-se as categorias de análise do discurso formuladas pelo professor Frédéric Sudre (2004), da Universidade de Montpellier, referidas por Humberto Nogueira Alcalá, também conhecidas como hipóteses interpretativas. Segundo tal modo de catalogação de posturas judiciais, o juiz doméstico pode desenvolver algumas hipóteses interpretativas frente ao sistema internacional, a saber: a) a interpretação extensiva, que vem a ser aquela em que o juiz leva além o alcance da jurisprudência interamericana, ampliando o campo de atuação do direito garantido, levando-o a situações antes não analisadas; b) a interpretação inovadora, que significa que juiz aborda alguns direitos contidos na $\mathrm{CADH}$ sobre os quais a Corte IDH não emitiu pronunciamentos até o presente; c) a interpretação corretiva, pela qual os juízes nacionais alteram a jurisprudência em razão de uma condenação por parte do Estado parte; d) a interpretação receptiva, podendo ser compreendida como aquela que se conforma com a "ratio decidendi" das sentenças da Corte IDH, tomando os juízes nacionais a iniciativa de alterar a jurisprudência, sem esperar que o seu Estado seja condenado, tendo em vista os standarts mínimos fixados pela Corte

variação for $\leq 20 \%$, têm-se baixa dispersão ou dados homogêneos. Caso contrário, os dados são ditos heterogêneos, ou seja, apresentam alta dispersão em torno da média.

${ }^{5}$ A assimetria mede o afastamento (diferença) da simetria dos dados em torno da média, portanto, são comparados os valores da média, da mediana e da moda. Se os valores forem coincidentes, tem-se um conjunto de dados simétrico. Esta condição é bem particular e difícil de ser encontrada em casos reais. Na prática, os conjuntos apresentam assimetria fraca, moderada ou forte: $\left|S_{K}\right| \leq 0,15 ; 0,15<\left|S_{K}\right| \leq 0,50 ;\left|S_{K}\right|>0,50$, respectivamente (Kazmier, 1982, p.33).

${ }^{6} \mathrm{O}$ número de decisões se justifica, porque em um dos subitens se acharam apenas 13 decisões, o que, ao lado dos 12 subitens outros - demandando, cada um, análise de 30 decisões, chegando-se ao total de 360 julgados -, totaliza o número de 373 julgados. 
IDH em outras decisões; e) a interpretação neutralizadora, que se trata de uma estratégia de contornar ou de evitar a interpretação da Corte IDH, ao criar uma interpretação forçada do direito nacional que, a pretexto de seguir a jurisprudência internacional, a sevicia; e f) a interpretação discordante, por meio da qual o juiz nacional considera expressamente incorreta a resolução internacional e deixa de aplicá-la (ALCALÁ, 2012, p.57-140).

A sofisticada classificação do autor mencionado, no entanto, revelou-se inadequada para analisar as decisões do TJPR em face dos julgados da Corte IDH, uma vez que a imensa maioria das decisões do Órgão jurisdicional doméstico avaliadas, como se verá adiante, não citou ou interpretou nenhum tratado internacional, nem ao menos para descumpri-lo ou emprestar-lhe sentido diferente daquele empregado pela Corte IDH, tornando portanto inútil a análise do discurso que se procederia sobre as decisões e que teria permitido identificar qual o tipo de interpretação utilizada pelos desembargadores do TJPR para que suas decisões dialogassem com aquelas proferidas no SIDH.

Na impossibilidade de utilizar-se a análise do discurso, optou-se por uma tipologia mais simples para classificar as decisões do TJPR, a saber: interpretação similar (harmônica) ou interpretação contrária à jurisprudência da Corte IDH.

Não se pode deixar de registrar que algumas decisões foram desconsideradas - tidas por prejudicadas -, mesmo fazendo parte da amostra, porque não se enquadraram em quaisquer das hipóteses referidas, pois não correspondiam à temática dos direitos humanos ou não puderam ser acessadas por serem cobertas pelo segredo de justiça.

\section{ANÁlise DAS DECISÕES DO TRIBUNAL DE JUSTIÇA DO PARANÁ QUE ENFRENTAM TEMAS DEBATIDOS NA CORTE IDH}

Selecionada a amostra, passou-se à análise dos acórdãos, sob diferentes prismas. Cada um dos seis temas será analisado à luz de vários pontos jurídicos, de modo que é possível sob a perspectiva de um deles o julgado se mostre compatível com a jurisprudência da Corte, e em outros não.

\subsection{Dados encontrados em cada um dos seis temas pesquisados}

No tema "deslocamento forçado", o nível de observância, por parte do TJPR, da jurisprudência da Corte IDH foi aferido mediante análise de 30 julgados do TJPR a partir de sete perspectivas diferentes (número de enunciados da Corte IDH), de modo que se chegou a 210 pontos analisados. Eis a configuração estatística do que foi apurado neste item da pesquisa, primeiro em relação à classificação entre interpretações de normas domésticas ou internacionais (Tabela 9).

Tabela 9: Amostra dos julgados do TJPR colhidos no item Deslocamento Forçado

Pontos em que se

N. total de pontos interpretou tratados

analisados - percentual internacionais do SIDH percentual
Trechos fundamentados apenas em normas nacionais - percentual

$210^{7}-100,00 \% \quad 0-0,00 \% \quad 210-100,00 \%$

Fonte: Adaptado de (BRASIL, 2015).

Este número é o resultado das 30 decisões vistas vezes as sete perspectivas que cada uma delas foi analisada. Este procedimento será repetido em todos os demais itens. 
No tocante às análises feitas a partir de julgados que trabalharam apenas com as categorias do direito nacional, omitindo-se em utilizar elementos normativos do SIDH, foi feita nova categorização, separando os pontos jurídicos em que a interpretação nacional produziu resultados similares aos que seriam produzidos, se fosse adotada interpretação de acordo com a Corte IDH, e os que geraram diferentes resultados (Tabela 10).

Tabela 10: Pontos jurídicos analisados

\begin{tabular}{|c|c|c|c|c|}
\hline & $\begin{array}{l}\text { N. total de } \\
\text { pontos com } \\
\text { fundamentação } \\
\text { de direito } \\
\text { doméstico - } \\
\text { percentual }\end{array}$ & $\begin{array}{l}\text { N. de pontos } \\
\text { com resultado } \\
\text { similar ao } \\
\text { preconizado } \\
\text { pelo SIDH - } \\
\text { percentual }\end{array}$ & $\begin{array}{l}\text { N. de pontos } \\
\text { com resultado } \\
\text { diverso ao } \\
\text { preconizado } \\
\text { pelo SIDH - } \\
\text { percentual }\end{array}$ & $\begin{array}{l}\text { N. de pontos } \\
\text { prejudicadas - } \\
\text { percentual }\end{array}$ \\
\hline$A^{8}$ & $30-100 \%$ & $0-0,00 \%$ & $6-20,00 \%$ & $24-80,00 \%$ \\
\hline B & $30-100 \%$ & $0-0,00 \%$ & $6-20,00 \%$ & $24-80,00 \%$ \\
\hline $\mathrm{C}$ & $30-100 \%$ & $0-0,00 \%$ & $6-20,00 \%$ & $24-80,00 \%$ \\
\hline $\mathrm{D}$ & $30-100 \%$ & $0-0,00 \%$ & $6-20,00 \%$ & $24-80,00 \%$ \\
\hline $\mathrm{E}$ & $30-100 \%$ & $0-0,00 \%$ & $6-20,00 \%$ & $24-80,00 \%$ \\
\hline $\mathrm{F}$ & $30-100 \%$ & $0-0,00 \%$ & $6-20,00 \%$ & $24-80,00 \%$ \\
\hline $\mathrm{G}$ & $30-100 \%$ & $0-0,00 \%$ & $6-20,00 \%$ & $24-80,00 \%$ \\
\hline $\begin{array}{ll}\text { Total de } \\
\text { pontos } \\
\text { analisados }\end{array}$ & $210-100 \%$ & $0-0,00 \%$ & $42-20,00 \%$ & $168-80,00 \%$ \\
\hline
\end{tabular}

Fonte: Adaptado de (BRASIL, 2015).

Diante desta tabela, verifica-se que cada um dos 30 julgados apreciados foi objeto de sete diferentes análises, com resultados diversos. Deste modo, neste tema, para se ter melhor compreensão do percentual em que se cumpriu a jurisprudência da Corte IDH, decidiu-se considerar cada decisão por sete vezes (o número de diferentes prismas a partir dos quais foi avaliada), chegando-se, à quantidade de 210 comparações feitas entre a jurisprudência dos dois Tribunais.

Neste contexto, como visto acima, um quinto (20\%) dos pontos analisados ostentou interpretação diversa do TJPR para com a Corte IDH. Não se constatou um único julgado em que a interpretação operada pelo TJPR tenha sido conforme (ou tenha levado a um entendimento conforme) a jurisprudência da Corte IDH. Em outros 168 pontos, não foi possível maior avaliação, tendo em vista que o caso concreto não discutia a mesma questão jurídica definida pela Corte IDH, restando prejudicada a análise. Considerando-se apenas os cotejamentos válidos - isto é, excluindose os prejudicados, pela não adequação da matéria jurídica discutida -, tem-se $100 \%$ de manifestações do TJPR diversas da Corte IDH.

Em outras palavras, no tema do deslocamento compulsória, em $100 \%$ dos casos os julgados do TJPR descumpriram os parâmetros protetivos impostos pela Corte IDH.

As 30 decisões do TJPR foram cotejadas com sete enunciados de jurisprudência da Corte IDH sobre o tema, o que se fez da seguinte maneira.

\footnotetext{
${ }^{8}$ As letras representam os enunciados de jurisprudência da Corte IDH.
} 
Localizaram-se cinco julgados a partir do emprego do argumento “' direitos humanos' e desapropriação", sendo analisado, como amostra, apenas um deles escolhido aleatoriamente (decisão 774086-1), em que o TJPR não adotou, nem ao menos implicitamente, o conceito amplo de deslocamento forçado da lavra da Corte IDH, visto que sustentou aquele tribunal que não basta haver o deslocamento do arrendatário para sua indenização, devendo este provar os prejuízos econômicos que sofrera com a sua desapropriação para a construção de barragem hidrelétrica. Aqui, tem-se interpretação inteiramente feita com base no direito nacional e com resultado diverso do que ocorreria caso se seguissem os precedentes da Corte IDH.

Já com a palavra-chave "desapropriação e hidrelétrica", surgiram 151 decisões, das quais se analisaram 22. Destas, 19 julgados (autos n. 1025768-4, 1061055-8, 1.277.840-8, 1265652-7, 12627859-7, 1227239-0, 1300251-4, 1113049-5, 1300711-5-4, 1264316-2, 1266319-1, 12621791, 1085263-2, 1022436-5, 1194761-4, 1197945-2, 1084029-6 e 494567-1) não trataram do tema deslocamento forçado, seja porque trataram de ação de desapropriação apenas com as categorias do direito tradicional de propriedade, seja porque cuidaram de ação possessória tradicional, contra pessoas que haviam invadido área pública fazia pouco tempo, seja porque trataram de questões ambientais.

Nos autos n. 833723-5, a $18^{\text {a }}$ Câmara Cível do TJPR julgou improcedente apelação interposta por empresa hidrelétrica, que se insurgiu contra sentença que determinou fosse indenizado posseiro de área desapropriada para a edificação de barragem hidrelétrica. Afirmou o TJPR que o fato de o proprietário do imóvel já ter sido indenizado no processo expropriatório nada impede que o posseiro, que não participou da ação, venha requerer a reparação pelas benfeitorias que realizou no imóvel. Toda a fundamentação girou em torno dos pressupostos do Código Civil para a indenização de benfeitorias e a discussão sobre posse de boa-fé, ou não. O TJPR reconheceu, ainda, o direito dos pescadores que foram afetados pela usina, com a diminuição da quantidade e qualidade dos peixes, obter indenização pela diminuição de sua atividade econômica. Esta decisão preservou o direito dos posseiros, afetados com a construção do empreendimento, todavia o fez em termos da legislação e jurisprudência nacionais apenas. E mais: deixou de levar em consideração os parâmetros internacionais para os deslocados compulsoriamente, categoria a que se encaixam os posseiros em questão. Poderia ter-lhes concedido o direito à indenização não apenas pelas benfeitorias ou pela perda de produtividade meramente econômica, mas também pelos danos imateriais oriundos da perda compulsória da residência, da perda de terra, marginalização, graves repercussões psicológicas, desemprego, empobrecimento e deterioração das condições de vida, incremento das enfermidades e da mortalidade, a perda de acesso à propriedade comum, a insegurança alimentar e a desarticulação social. Também, não foi analisado o dever de o empreendedor arcar com os custos de novas moradias, programas de saúde, etc. Assim, operou-se interpretação diferente da que possivelmente ocorreria se se seguissem os parâmetros desenhados pela Corte IDH.

A apelação cível $n^{\circ} 1313730-5$ tratou de interdito proibitório em que os autores alegaram ter sido molestados e assediados por prepostos da requerida a pretexto de cadastrá-los em razão de que suas áreas serão atingidas pela construção de usinas hidrelétricas. Com fundamento no art. 932 do Código Civil, o TJPR entendeu que, no caso, não era plausível vislumbrar justo receio de turbação ou esbulho da posse, visto ser o cadastramento medida necessária à construção de qualquer usina, inclusive para balizar eventual negociação amigável para fins de desapropriação. Fundamentou-se em precedentes do próprio TJPR em casos semelhantes e em legislação nacional. Todavia, os precedentes da Corte IDH não foram levados em consideração, o que gerou reflexos na decisão. Primeiro, porque entendeu o TJPR que a mera certeza de indenização já era suficiente para afastar qualquer potencial de ilicitude e de agressão aos direitos dos autores, sobretudo no que 
se refere à caracterização da indenização como elemento a exorcizar a remoção compulsória. Esqueceu-se o TJPR ( $18^{a}$ Câmara Cível) que a obra em questão trata de deslocamento compulsório de famílias, o que gera riscos iminentes de ocorrência de violação de direitos humanos com graves implicações não só ao direito de propriedade como a outros direitos relativos à dignidade da pessoa humana.

Nos autos da apelação cível 1328868-7, cuida-se de ação de indenização em face de companhia de energia elétrica, por terem sido os autores afetados com a construção de usina hidrelétrica. O TJPR ( $5^{\text {a }}$ Câmara Cível) manteve a sentença, ao fundamento de que "em nenhum momento os autores lograram êxito em comprovar que faziam jus ao enquadramento em alguma das modalidades previstas no programa de reassentamento decorrente da construção da Usina Hidrelétrica de Salto Caxias". Os apelantes residiam e trabalhavam no local como parte do núcleo familiar dos proprietários do imóvel, não possuindo qualquer independência na produção. Aqui, portanto, o critério de remoção compulsória não foi empregado, visto que apenas considerou o TJPR, para fins de indenização no caso concreto, a propriedade afetada, deixando de considerar os prejuízos causados às pessoas removidas compulsoriamente de seus lares. Tem-se, pois, interpretação nacional diferente da trabalhada pela Corte IDH.

Mediante o uso do argumento "desapropriação e barragem", 47 decisões foram encontras, das quais sete compuseram a amostra efetivamente analisada, nos termos dos cálculos feitos no capítulo dois desta pesquisa.

Cinco destes processos (autos n. 1342116-0, 686031-5, 379353-9, 833723-5 e 372087-2) tratam de ações sobre direitos meramente patrimoniais, nada tendo a ver com remoção compulsória.

Nos autos da apelação cível n o 351147-3, o TJPR ( 8 a Câmara Cível) julgou apelação contra sentença que julgou procedente pedido de indenização em razão de alagamento de área arrendada em usina hidrelétrica, o que forçou o arrendatário a deixar suas terras. A sentença que condenou a empresa a indenizar o arrendatário foi mantida, visto que

Se o autor, como arrendatário, perdeu, com o alagamento, a área que tinha para cultivar, sofreu prejuízo, e como tal merece ser indenizado; [...] a três, o funcionário da apelante confirma que a mesma não indenizava pessoas pelo simples fato de serem arrendatário e terem as terras atingidas, o que significa dizer que a empresa, apesar de saber o prejuízo que causava aos arrendatários, não se propunha a indenizá-los.

Pois bem. Apesar de o TJPR ter julgado a apelação em favor do arrendatário, não se valeu da gramática do DIDH, limitando-se a trabalhar com categorias jurídicas do direito interno meramente patrimoniais (valores perdidos com áreas de efetivo cultivo), o que baixou os valores a serem pagos ao requerente. Assim, tem-se interpretação fundamentada no direito doméstico, que tomaria outro rumo caso fosse feita à luz do direito internacional.

Ao fim, nos autos $n^{\circ} 760966-5$, o TJPR (4ª Câmara Cível) julgou recurso de apelação interposto em face de sentença que julgou improcedentes os pedidos apresentados em ações civis públicas por associações socioambientais. Entre outros pedidos, a apelante requereu a condenação de danos morais do responsável por barragem hidrelétrica, tendo em vista os danos sofridos pelos indivíduos que se viram despojados de suas propriedades. Todavia, o TJ negou-lhes o pedido, lançando sucintos fundamentos, ao argumento de que "não há dúvidas de que a situação vivida pelos apelantes é delicada, entretanto a ocorrência não é suficiente para a caracterização de danos morais". Aqui, claramente, foi ignorado o conceito de removidos compulsoriamente, pela Corte IDH, porquanto o TJPR lhes negou direito à indenização, por ausência de ato ilícito, 
desconsiderando que a remoção por si só é categoria jurídica a gerar efeitos de mesma natureza. Tem, uma vez mais, interpretação com base em ferramentas jurídicas domésticas.

O segundo assunto, referente a "questões de gênero", em razão da riqueza jurisprudencial da Corte IDH, foi dividido em outros três subitens, a saber: discriminação baseada em gênero, corpo e maternidade e violência de gênero. Todas as três seções do tema principal foram analisadas, como já assinalados, tendo-se como paradigma alguns precedentes da Corte IDH, os quais foram sintetizados pelos autores em seis resumos. Estes seis enunciados formulados pelos autores em vista da jurisprudência da Corte IDH sobre o tema e seus consectários foram utilizados como parâmetros a serem comparados com decisões da lavra do TJPR, sobre casos similares (Tabela 11).

Neste item referente aos direitos de gênero, composto pelos três subitens acima descritos, analisaram-se 90 decisões, à razão de seis prismas por cada um dos julgados, o que gerou a configuração mostrada na Tabela 12.

\section{Tabela 11: Amostra dos julgados do TJPR colhidos no item Gênero}

\begin{tabular}{ccc}
\hline $\begin{array}{c}\text { N. total de pontos - } \\
\text { percentual }\end{array}$ & $\begin{array}{c}\text { Pontos a interpretar } \\
\text { tratados internacionais do } \\
\text { SIDH - percentual }\end{array}$ & $\begin{array}{c}\text { Pontos fundamentados } \\
\text { apenas em normas } \\
\text { nacionais - percentual }\end{array}$ \\
\hline $540-100,00 \%$ & $0-0,00 \%$ & $540-0,00 \%$ \\
\hline
\end{tabular}

Fonte: Adaptado de (BRASIL, 2015).

Tabela 12: Pontos jurídicos analisados item Gênero

\begin{tabular}{|c|c|c|c|c|}
\hline & $\begin{array}{c}\text { N. total de } \\
\text { decisões com } \\
\text { fundamentação } \\
\text { de direito } \\
\text { doméstico - } \\
\text { percentual }\end{array}$ & $\begin{array}{l}\text { N. de julgados } \\
\text { com resultado } \\
\text { similar ao } \\
\text { preconizado } \\
\text { pelo SIDH - } \\
\text { percentual }\end{array}$ & $\begin{array}{l}\text { N. de julgados } \\
\text { com resultado } \\
\text { diverso ao } \\
\text { preconizado } \\
\text { pelo SIDH - } \\
\text { percentual }\end{array}$ & $\begin{array}{l}\text { N. de decisões } \\
\text { prejudicadas - } \\
\text { percentual }\end{array}$ \\
\hline $\mathrm{A}^{9}$ & $90-100 \%$ & $1-1,11 \%$ & $27-30,00 \%$ & $62-71,11 \%$ \\
\hline $\mathrm{B}$ & $90-100 \%$ & $3-3,33 \%$ & $18-2,00 \%$ & $69-76,66 \%$ \\
\hline $\mathrm{C}$ & $90-100 \%$ & $3-3,33 \%$ & $10-1,11 \%$ & $77-85,55 \%$ \\
\hline $\mathrm{D}$ & $90-100 \%$ & $3-3,33 \%$ & $24-26,66 \%$ & $63-7,00 \%$ \\
\hline $\mathrm{E}$ & $90-100 \%$ & $5-5,55 \%$ & $42-46,66 \%$ & $43-47,77 \%$ \\
\hline $\mathrm{F}$ & $90-100 \%$ & $25-27,77 \%$ & $0-0,00 \%$ & $65-72,22 \%$ \\
\hline $\begin{array}{c}\text { Total de } \\
\text { pontos } \\
\text { analisados }\end{array}$ & $540-100 \%$ & $40-7,40 \%$ & $121-22,40 \%$ & $379-70,18 \%$ \\
\hline
\end{tabular}

Fonte: Adaptado de (BRASIL, 2015).

Diante do quadro com as estatísticas colhidas a respeito do tema em foco, constata-se que a grande maioria (mais de 70\%) dos pontos analisados a partir das 90 decisões do TJPR, não guarda pertinência fática com os entendimentos da Corte IDH, não podendo, pois, ser examinados. Dos 161 pontos efetivamente analisados (em torno de $30 \%$ do total de questões examinadas), verificouse que em mais de $75 \%$ deles - em 121, mais precisamente - o TJPR lançou mão de interpretações próximas aos parâmetros estabelecidos pela Corte IDH, evidenciando-se, assim, que, no que se

\footnotetext{
${ }^{9}$ As letras representam os enunciados de jurisprudência da Corte IDH.
} 
refere aos direitos inerentes a questões de gênero, a Corte paranaense tem seguido os parâmetros internacionais na maioria dos casos. Esse respeito, contudo, deu-se de modo tácito, visto que nem a jurisprudência dos órgãos do SIDH, nem os tratados internacionais respectivos foram citados nos julgados analisados. No geral, o ponto em que mais se distanciou o TJPR dos precedentes da Corte IDH foi o "F", visto que em diversos casos o TJPR deixou de, expressamente, garantir o direito à mulher de acompanhar o desenrolar de procedimento em que figura como vítima.

Infelizmente, ainda que se possa firmar que o TJPR tenha observado parâmetros da Corte IDH em questões de gênero analisadas, elide-se o necessário "diálogo" entre cortes, que poderia consistir em uma importante ferramenta do Judiciário para exigir do governo brasileiro um maior compromisso com a efetividade na proteção dos Direitos Humanos preconizada no Constituição brasileira.

Com o argumento "discriminação e mulher e gênero", 63 decisões foram levantadas, das quais, pelos critérios estatísticos explicados anteriormente, uma foi examinada (Apelação Criminal n. ${ }^{\circ}$ 1.348.266-9). Trata-se de conflito de competência suscitado por Vara Criminal, que pretendia fosse afastada a aplicabilidade da Lei Maria da Penha e, consequentemente, declarada a competência do Juizado Especial Criminal. Ao enfrentar o tema, o TJPR julgou procedente o conflito suscitado, declarando competente o Juizado Especial Criminal. No mérito, afastou a incidência da Lei n. 11.340/2006, sob o argumento de que não há qualquer violência de gênero ou situação de vulnerabilidade, visto que a vítima e a acusada são cunhadas. Ora, de fato, as agressões apuradas não foram especialmente dirigidas à vítima mulher, em razão de sua condição de gênero, do que se conclui que não há qualquer violação às disposições da Convenção do Belém do Pará. Assim, o mote "a" dos enunciados da Corte IDH foi atendido, mesmo sem referência aos documentos internacionais, bem como os demais itens se referem a assuntos diversos, restando prejudicada a análise.

A partir da palavra-chave "Maria da Penha", localizaram-se 1853, tendo sido analisadas 29 delas (Apelações Criminais n. ${ }^{\circ}$ 1.350.306-9, 1.383.671-2, 1.364.827-2, 1.229.926-6, 1.290.4228, 1.299.193-8, 1.302.963-7, 1.317.700-3, 1.297.014-4, 1.292.676-4, 1.285.152-8, 1.285.810-5, $1.285 .631-4,1.178 .311-4,1.274 .318-9,1.258 .470-4,1.278 .406-0,1.275 .473-9,1.255 .515-6$, $1.233 .520-3,1.245 .891-8,1.235 .163-6,527.675-1,1.159 .769-8,1.121 .634-9,1.547 .018-4$, 1.622.964-3, 1.237.865-3 e 1.245.644-6. Destas, encontraram-se, em geral, interpretações semelhantes à da Corte IDH nos itens "a", "b", "e", bem como interpretações diversas no item "f". As decisões referem-se a processos criminais envolvendo agressões contra a mulher.

O terceiro assunto "criança e adolescente", em razão da complexidade e variedade da jurisprudência da Corte IDH sobre o tema, foi dividido em outros quatro subitens, a saber: interesse superior, direito à vida, direito à integridade pessoal e direito à liberdade pessoal. Todos os quatro desdobramentos do tema principal foram analisados, como já assinalado em outros itens, sob as lentes de precedentes da Corte IDH, os quais foram sintetizados pelos autores em sete resumos. Cada um destes quatro subtemas, mencionados no início deste item, gerou vários argumentos, por intermédio dos quais se levantaram decisões do TJPR a serem comparadas com os sete enunciados da Corte IDH. Outrossim, cada um dos verbetes feitos a partir da jurisprudência da Corte IDH deu ocasião à análise de 30 julgados do TJPR, totalizando a leitura de 120 decisões ao todo (apenas neste assunto). Assim, o total de apreciações feitas neste tema foi de 840 (Tabela 13). Os dados colhidos neste tema - ou nos quatro subitens do direito da criança e adolescente - encontram-se na Tabela 14, à luz dos sete enunciados de jurisprudência da Corte IDH acima transcritos. 


\begin{tabular}{|c|c|c|}
\hline \multicolumn{3}{|c|}{$\begin{array}{l}\text { Tabela 13: Amostra dos pontos jurídicos do TJPR colhidos no item Direito da } \\
\text { Criança e Adolescente }\end{array}$} \\
\hline $\begin{array}{l}\text { N. total de pontos - } \\
\text { percentual }\end{array}$ & $\begin{array}{c}\text { Pontos a interpretar } \\
\text { tratados internacionais do } \\
\text { SIDH - percentual }\end{array}$ & $\begin{array}{l}\text { Pontos fundamentados } \\
\text { apenas em normas } \\
\text { nacionais - percentual }\end{array}$ \\
\hline $840-100,00 \%$ & $0-0,00 \%$ & $840-0,00 \%$ \\
\hline
\end{tabular}

Fonte: Adaptado de (BRASIL, 2015).

Tabela 14: Pontos jurídicos analisados item Direito da Criança e Adolescente

\begin{tabular}{ccccc}
\hline & $\begin{array}{c}\text { N. total de } \\
\text { pontos com } \\
\text { fundamentação } \\
\text { de direito } \\
\text { doméstico - } \\
\text { percentual }\end{array}$ & $\begin{array}{c}\text { N. de pontos } \\
\text { com resultado } \\
\text { similar ao } \\
\text { preconizado } \\
\text { pelo SIDH - } \\
\text { percentual }\end{array}$ & $\begin{array}{c}\text { N. de pontos } \\
\text { com resultado } \\
\text { diverso ao } \\
\text { preconizado } \\
\text { pelo SIDH - } \\
\text { percentual }\end{array}$ & $\begin{array}{c}\text { N. de pontos } \\
\text { prejudicados - } \\
\text { percentual }\end{array}$ \\
\hline $\mathrm{A}^{10}$ & $120-100 \%$ & $3-2,50 \%$ & $0-0,00 \%$ & $106-88,33 \%$ \\
\hline $\mathrm{B}$ & $120-100 \%$ & $0-0,00 \%$ & $0-0,00 \%$ & $120-100,00 \%$ \\
\hline $\mathrm{C}$ & $120-100 \%$ & $16-13,33 \%$ & $0-0,00 \%$ & $104-86,66 \%$ \\
\hline $\mathrm{D}$ & $120-100 \%$ & $45-37,50 \%$ & $0-0,00 \%$ & $75-62,50 \%$ \\
\hline $\mathrm{E}$ & $120-100 \%$ & $0-0,00 \%$ & $0-0,00 \%$ & $120-100,00 \%$ \\
\hline $\mathrm{F}$ & $120-100 \%$ & $0-0,00 \%$ & $0-0,00 \%$ & $120-100,00 \%$ \\
\hline $\mathrm{G}$ & $120-100 \%$ & $2-16,66 \%$ & $10-8,33 \%$ & $108-90,00 \%$ \\
\hline $\begin{array}{c}\text { Total de } \\
\text { pontos }\end{array}$ & $840-100 \%$ & $66-7,85 \%$ & $21-2,50 \%$ & $753-89,64 \%$ \\
analisados & & & & \\
\hline
\end{tabular}

Fonte: Adaptado de (BRASIL, 2015).

Da leitura dos dados expostos, constata-se que todos os pontos analisados trabalharam com interpretação da legislação local, e a grande maioria (mais de 89\%) deles não guarda pertinência fática com os entendimentos da Corte IDH, não podendo, pois, ser examinados a fundo. Dos poucos pontos efetivamente analisados (em torno de $10 \%$ do total de questões examinadas), em número de 87 , verificou-se que em mais de $75 \%$ deles (em 66), o TJPR lançou mão de interpretações harmônicas com os parâmetros estabelecidos pela Corte IDH. Registre-se que tal obediência às determinações da Corte IDH, tal como no caso de discriminação baseada em gênero, se deu de modo tácito, visto que nem a jurisprudência dos órgãos do SIDH nem os tratados internacionais respectivos foram citados nos julgados analisados.

As primeiras decisões (como por exemplo a tomada no Agravo de Instrumento $\mathrm{n}^{\circ}$ 1340312-4) do TJPR analisadas foram colhidas a partir da utilização das palavras-chave "criança e "interesse superior", "adolescente e "interesse superior"” e "ECA e "interesse superior", tendo apresentado interpretação conforme nos itens "c" e "d" e disforme no "a". Nas demais, restou prejudicada a análise, tendo em vista tratar-se de temas diversos.

Também, levantaram-se julgados em que o TJPR inobservou o item "g" dos enunciados colhidos a partir da jurisprudência da Corte IDH, tendo em vista que não se aplicaram os requisitos previstos para a prisão preventiva, segundo o que a Corte IDH fixou, tais como para o

\footnotetext{
${ }^{10} \mathrm{As}$ letras representam os enunciados de jurisprudência da Corte IDH.
} 
desenvolvimento do processo ou para evitar iludir a aplicação da ação da Justiça. Utilizou-se o TJPR de requisitos de prevenção geral para a aplicação da tutela antecipada equivalente à prisão preventiva (Apelação Criminal n. 1355450-2. 2). O item "g" foi observado em alguns casos concretos (Habeas Corpus $\mathrm{n}^{\mathbf{0}}$ 1399458-6), visto que se aplicaram os requisitos previstos para a prisão preventiva, segundo o que a Corte IDH fixou, tais como para o desenvolvimento do processo ou para evitar iludir a aplicação da ação da Justiça. Todavia, não se utilizou o TJPR de citações do SIDH. Tal item não foi respeitado em outros julgados (Apelação Criminal n. 1191001-1).

Há outro conjunto de decisões (Apelação Cível n. 1308381-9) sobre a concessão de direitos sociais a crianças e adolescentes, tais como vagas em creche, em que o TJPR adotou a decisão que melhor preserva o direito à vida da criança e do seu desenvolvimento integral, mesmo não citando o SIDH, sobretudo considerando o direito à educação. $\mathrm{O}$ item "d" foi atendido.

Ainda dentro do mesmo subitem, verificaram-se decisões (como por exemplo a Apelação Criminal n. 1403419-0), em que o assunto tratado em nenhum momento algum tratou de questões pertinentes aos enunciados feitos a partir de manifestações da Corte IDH. São processos criminais em que o réu é pessoa adulta, de modo que a citação do termo "ECA" se deu, por exemplo, em função do crime de corrupção de menores. Assim, restou prejudicada a realização de análises comparativas entre as manifestações do TJPR e da Corte IDH.

No assunto referente ao "controle de convencionalidade", ao contrário do anterior, não foi particionado em outros subitens, tendo sido trabalhado com dois argumentos, a saber: "controle de convencionalidade" e controle de convencionalidade - este último sem aspas, de modo que se encontraram decisões contendo tais palavras em qualquer ordem. Com ambas as palavras de busca, encontraram-se apenas 13 decisões, as quais foram todas analisadas, sendo três julgados repetidos. No vertente tema, o nível de observância, por parte do TJPR, da jurisprudência da Corte IDH foi aferido mediante análise de 10 julgados do TJPR à luz de noves entendimentos da Corte IDH a respeito nesta linha de assunto. Da análise de todas as 10 decisões, verificou-se que apenas duas delas (sendo uma delas a adotada na Apelação Criminal n. 1317102-7) foi reconhecido o conceito de controle de convencionalidade e a obrigação de cumprir os documentos internacionais, tal como preconizado pela Corte IDH. Outrossim, as mesmas decisões reconheceram que a jurisprudência da Corte IDH deve ser levada em conta pelos órgãos jurisdicionais internos. Assim, as Tabelas 16 e 17 apresentam as configurações das decisões de controle de convencionalidade.

\begin{tabular}{|c|c|c|}
\hline \multicolumn{3}{|c|}{$\begin{array}{l}\text { Tabela 15: Amostra dos julgados do TJPR colhidos no item Controle de } \\
\text { Convencionalidade }\end{array}$} \\
\hline $\begin{array}{l}\text { N. total de julgados - } \\
\text { percentual }\end{array}$ & $\begin{array}{c}\text { Decisões a interpretar } \\
\text { tratados internacionais do } \\
\text { SIDH - percentual }\end{array}$ & $\begin{array}{c}\text { Julgados fundamentados } \\
\text { apenas em normas } \\
\text { nacionais - percentual }\end{array}$ \\
\hline $90-100,00 \%$ & $0-0,00 \%$ & $90-100 \%$ \\
\hline
\end{tabular}

Fonte: Adaptado de (BRASIL, 2015). 
Tabela 16: Pontos jurídicos analisados

\begin{tabular}{ccccc}
\hline & $\begin{array}{c}\text { N. total de } \\
\text { quesitos com } \\
\text { fundamentação } \\
\text { de direito } \\
\text { doméstico - } \\
\text { percentual }\end{array}$ & $\begin{array}{c}\text { N. de quesitos } \\
\text { com resultado } \\
\text { similar ao } \\
\text { preconizado } \\
\text { pelo SIDH - } \\
\text { percentual }\end{array}$ & $\begin{array}{c}\text { N. de quesitos } \\
\text { com resultado } \\
\text { diverso ao } \\
\text { preconizado } \\
\text { pelo SIDH - } \\
\text { percentual }\end{array}$ & $\begin{array}{c}\text { N. de quesitos } \\
\text { prejudicadas - } \\
\text { percentual }\end{array}$ \\
\hline $\mathrm{A}^{11}$ & $10-100 \%$ & $2-20,00 \%$ & $6-60,00 \%$ & $2-20,00 \%$ \\
\hline $\mathrm{B}$ & $10-100 \%$ & $2-20,00 \%$ & $6-60,00 \%$ & $2-20,00 \%$ \\
\hline $\mathrm{C}$ & $10-100 \%$ & $2-20,00 \%$ & $6-60,00 \%$ & $2-20,00 \%$ \\
\hline $\mathrm{D}$ & $10-100 \%$ & $0-0,00 \%$ & $0-0,00 \%$ & $10-100,00 \%$ \\
\hline $\mathrm{E}$ & $10-100 \%$ & $0-0,00 \%$ & $5-50,00 \%$ & $5-50,00 \%$ \\
\hline $\mathrm{F}$ & $10-100 \%$ & $0-0,00 \%$ & $0-0,00 \%$ & $10-100,00 \%$ \\
\hline $\mathrm{G}$ & $10-100 \%$ & $1-10,00 \%$ & $6-60,00 \%$ & $3-30,00 \%$ \\
\hline $\mathrm{H}$ & $10-100 \%$ & $1-10,00 \%$ & $5-50,00 \%$ & $4-40,00 \%$ \\
\hline I & $10-100 \%$ & $2-20,00 \%$ & $6-60,00 \%$ & $2-20,00 \%$ \\
\hline $\begin{array}{c}\text { Total de } \\
\text { pontos }\end{array}$ & $90-100 \%$ & $10-11,11 \%$ & $40-44,44 \%$ & $40-44,44 \%$ \\
analisados & & & & \\
\hline
\end{tabular}

Fonte: Adaptado de (BRASIL, 2015).

Como visto acima, quase metade (44\%) dos pontos analisados adotou interpretação diferente da adotada pelo TJPR para com a Corte IDH; apenas em 11\% constatou-se interpretação similar. Em outros 40 pontos, não foi possível maior avaliação, tendo em vista que o caso concreto não discutia a mesma questão jurídica definida pela Corte IDH, restando prejudicada a análise. Considerando apenas os cotejamentos válidos - isto é, excluindo-se os prejudicados -, tem-se $80 \%$ de manifestações do TJPR desafinadas com os entendimentos da Corte IDH. Portanto, num contexto geral, neste item (controle de convencionalidade), dessume-se que o TJPR é refratário em acompanhar a jurisprudência da Corte IDH.

Quanto ao assunto "liberdade pessoal" (o quinto item analisado neste capítulo), trabalhouse com nove argumentos, a saber: "direito à liberdade pessoal", "direito à liberdade", "privação de liberdade", "homologação do flagrante", "legalidade do flagrante", "prisão preventiva", "nota de culpa", "informação sobre a prisão" e "audiência de custódia". No vertente tema, o nível de observância, por parte do TJPR, da jurisprudência da Corte IDH foi aferido mediante análise de 30 julgados do TJPR (Recursos em Sentido Estrito $n^{\circ} 1417696-6$ e $n^{\circ} 1272217-9$ ) à luz de cinco entendimentos da Corte IDH a respeito nesta linha de assunto. A configuração do que se encontrou nas decisões analisadas consta nas Tabelas 17 e 18.

\footnotetext{
${ }^{11}$ As letras representam os enunciados de jurisprudência da Corte IDH.
} 


\begin{tabular}{|c|c|c|}
\hline \multicolumn{3}{|c|}{$\begin{array}{c}\text { Tabela 17: Amostra dos julgados do TJPR colhidos no item Direito à Liberdade } \\
\text { Pessoal }\end{array}$} \\
\hline $\begin{array}{l}\text { N. total de pontos - } \\
\text { percentual }\end{array}$ & $\begin{array}{c}\text { Pontos a interpretar } \\
\text { tratados internacionais do } \\
\text { SIDH - percentual }\end{array}$ & $\begin{array}{l}\text { Pontos fundamentados } \\
\text { apenas em normas } \\
\text { nacionais - percentual }\end{array}$ \\
\hline $150-100,00 \%$ & $0-0,00 \%$ & $150-100 \%$ \\
\hline
\end{tabular}

Fonte: Adaptado de (BRASIL, 2015).

Tabela 18: Pontos jurídicos analisados

\begin{tabular}{ccccc}
\hline & $\begin{array}{c}\text { N. total de } \\
\text { quesitos com } \\
\text { fundamentação } \\
\text { de direito } \\
\text { doméstico - } \\
\text { percentual }\end{array}$ & $\begin{array}{c}\text { N. de quesitos } \\
\text { com resultado } \\
\text { similar ao } \\
\text { preconizado } \\
\text { pelo SIDH - } \\
\text { percentual }\end{array}$ & $\begin{array}{c}\text { N. de quesitos } \\
\text { com resultado } \\
\text { diverso ao } \\
\text { preconizado } \\
\text { pelo SIDH - } \\
\text { percentual }\end{array}$ & $\begin{array}{c}\text { N. de quesitos } \\
\text { prejudicadas - } \\
\text { percentual }\end{array}$ \\
\hline $\mathrm{A}^{12}$ & $30-100 \%$ & $26-86,66 \%$ & $4-13,33 \%$ & $0-0,00 \%$ \\
\hline $\mathrm{B}$ & $30-100 \%$ & $29-96,66 \%$ & $1-3,33 \%$ & $0-0,00 \%$ \\
\hline $\mathrm{C}$ & $30-100 \%$ & $10-13,33 \%$ & $20-66,66 \%$ & $0-0,00 \%$ \\
\hline $\mathrm{D}$ & $30-100 \%$ & $12-40,00 \%$ & $18-60,00 \%$ & $0-0,00 \%$ \\
\hline E & $30-100 \%$ & $0-0,00 \%$ & $30-100,00 \%$ & $0-0,00 \%$ \\
\hline $\begin{array}{c}\text { Total de } \\
\text { pontos }\end{array}$ & $150-100 \%$ & $77-51,33 \%$ & $73-48,66 \%$ & $0-0,00 \%$ \\
analisados & & & & \\
\hline
\end{tabular}

Fonte: Adaptado de (BRASIL, 2015).

Neste tema (liberdade pessoal), para se ter melhor compreensão do percentual em que se cumpriu a jurisprudência da Corte IDH, decidiu-se considerar cada decisão por cinco vezes (o número de diferentes prismas a partir dos quais foi avaliada). Tem-se, portanto, 150 cotejamentos feitos entre a jurisprudência dos dois Tribunais, a partir das 30 decisões do TJPR. Neste contexto, como visto acima, todos os quesitos foram fundamentados com legislação nacional e quase metade (48\%) deles ostentaram interpretação distante do da jurisprudência da Corte IDH; em 51\%, constatou-se interpretação conforme a Corte IDH. Portanto, num contexto geral, neste subitem (liberdade pessoal), é possível cravar que não observou a contento o TJPR a jurisprudência da Corte $\mathrm{IDH}$, nem ao menos tacitamente.

O último assunto - direito à liberdade de expressão em sentido amplo - foi dividido em outros três subitens, a saber: liberdade de expressão em sentido estrito, direito de resposta e direito de acesso à informação. $\mathrm{O}$ tema foi trabalhado mediante a análise de 90 julgados do TJPR (30 por subtema) à luz de alguns dos entendimentos da Corte IDH a respeito do tema, mais precisamente dos oito breves epítomes da jurisprudência da Corte IDH. Os dados colhidos neste tema - ou nos três subitens do gênero liberdade de expressão - constam das Tabelas 19 e 20, à luz dos oito enunciados de jurisprudência da Corte IDH acima transcritos.

\footnotetext{
${ }^{12} \mathrm{As}$ letras representam os enunciados de jurisprudência da Corte IDH.
} 


\begin{tabular}{|c|c|c|}
\hline \multicolumn{3}{|c|}{$\begin{array}{l}\text { Tabela 19: Amostra dos julgados do TJPR colhidos no item Direito à liberdade de } \\
\text { expressão }\end{array}$} \\
\hline $\begin{array}{l}\text { N. total de pontos - } \\
\text { percentual }\end{array}$ & $\begin{array}{c}\text { Pontos a interpretar } \\
\text { tratados internacionais do } \\
\text { SIDH - percentual }\end{array}$ & $\begin{array}{l}\text { Pontos fundamentados } \\
\text { apenas em normas } \\
\text { nacionais - percentual }\end{array}$ \\
\hline $720-100,00 \%$ & $0-0,00 \%$ & $720-100 \%$ \\
\hline
\end{tabular}

Fonte: Adaptado de (BRASIL, 2015).

Tabela 20: Pontos jurídicos analisados

\begin{tabular}{ccccc}
\hline & $\begin{array}{c}\text { N. total de } \\
\text { quesitos com } \\
\text { fundamentação } \\
\text { de direito } \\
\text { doméstico - } \\
\text { percentual }\end{array}$ & $\begin{array}{c}\text { N. de quesitos } \\
\text { com resultado } \\
\text { similar ao } \\
\text { preconizado } \\
\text { pelo SIDH - } \\
\text { percentual }\end{array}$ & $\begin{array}{c}\text { N. de quesitos } \\
\text { com resultado } \\
\text { diverso ao } \\
\text { preconizado } \\
\text { pelo SIDH - } \\
\text { percentual }\end{array}$ & $\begin{array}{c}\text { N. de quesitos } \\
\text { prejudicadas } \\
\text { - percentual }\end{array}$ \\
\hline $\mathrm{A}^{13}$ & $90-100 \%$ & $0-0 \%$ & $35-38,00 \%$ & $55-61,11 \%$ \\
\hline $\mathrm{B}$ & $90-100 \%$ & $5-5,55 \%$ & $5-5,55 \%$ & $80-88,88 \%$ \\
\hline $\mathrm{C}$ & $90-100 \%$ & $13-14,44 \%$ & $17-18,88 \%$ & $60-66,66 \%$ \\
\hline $\mathrm{D}$ & $90-100 \%$ & $7-7,77 \%$ & $17-18,88 \%$ & $66-73,33 \%$ \\
\hline $\mathrm{E}$ & $90-100 \%$ & $5-5,55 \%$ & $21-23,33 \%$ & $64-71,11 \%$ \\
\hline $\mathrm{F}$ & $90-100 \%$ & $10-11,11 \%$ & $18-20,00 \%$ & $62-68,88 \%$ \\
\hline $\mathrm{G}$ & $90-100 \%$ & $2-2,22 \%$ & $1-1,11 \%$ & $87-96,66 \%$ \\
\hline $\mathrm{H}$ & $90-100 \%$ & $0-0 \%$ & $0-0 \%$ & $90-100 \%$ \\
\hline $\begin{array}{c}\text { Total de } \\
\text { pontos }\end{array}$ & $720-100 \%$ & $42-5,83 \%$ & $114-15,83 \%$ & $564-78,33 \%$ \\
analisados & & & & \\
\hline
\end{tabular}

Fonte: Adaptado de (BRASIL, 2015).

Da leitura dos dados expostos, constata-se que a grande maioria dos pontos analisados (564) das decisões do TJPR (como por exemplo as Apelações Cíveis n $1269650-9$ e $n^{\circ}$ 12660569). não guarda pertinência fática com os entendimentos da Corte IDH, não podendo, pois, ser examinados. Dos pontos efetivamente analisados, verificou-se que em mais de $73 \%$ deles (114 deles) o TJPR lançou mão de interpretações divergentes com os parâmetros estabelecidos pela Corte IDH.

\section{O MONÓLOGO DO TJPR}

$\mathrm{Na}$ pesquisa analisaram-se 373 decisões, escolhidas de modo não arbitrário, que representam a amostra de uma população de mais de 60 mil julgados. A amostra representa estatisticamente a totalidade do universo analisado. Tais decisões foram lidas à luz de diferentes prismas, a depender do tema ao qual pertenciam, de modo que um julgado do TJPR deu ocasião para a feitura de diversas análises, podendo em alguns pontos ter interpretado o direito em conformidade com a Corte IDH e em outros, não. Assim, o resultado da pesquisa prática não passa

\footnotetext{
${ }^{13}$ As letras representam os enunciados de jurisprudência da Corte IDH.
} 
pela quantidade de decisões classificadas num determinado sentido - o que não se fez aqui -, mas sim pelo número, em cada um dos julgados, de quesitos etiquetados sob as hipóteses interpretativas, visto que estes melhor expressam a postura do TJPR nos últimos anos a respeito do DIDH trabalhados pelo SIDH, especialmente pela Corte IDH.

Analisaram-se, da jurisprudência do TJPR, somando-se os seis temas já descritos, 2550 pontos, a partir dos enunciados da Corte IDH. Destes, em 2540 o TJ silenciou acerca de normativas ou decisões do SIDH; nas 10 restantes houve interpretação (conforme ou não) de algum tratado internacional. A Tabela 21 ilustra essa situação.

\begin{tabular}{ccc}
\hline \multicolumn{3}{c}{ Tabela 21: Amostra dos pontos analisados a partir de julgados do TJPR } \\
\hline $\begin{array}{c}\text { N. total de pontos }- \\
\text { percentual }\end{array}$ & $\begin{array}{c}\text { Pontos a interpretar } \\
\text { tratados internacionais do } \\
\text { SIDH - percentual }\end{array}$ & $\begin{array}{c}\text { Pontos fundamentados } \\
\text { apenas em normas } \\
\text { nacionais - percentual }\end{array}$ \\
\hline $2550-100,00 \%$ & $10-0,44 \%$ & $2540-99,60 \%$ \\
\hline
\end{tabular}

Fonte: Adaptado de (BRASIL, 2015).

A Tabela 22 contém a classificação dos itens, verificados nos acórdãos que trabalharam apenas com interpretações nacionais.

Tabela 22: Classificação dos temas principais

\begin{tabular}{lcccc}
\hline Temas principais & $\begin{array}{c}\text { N. total de } \\
\text { quesitos com } \\
\text { fundamentação } \\
\text { de direito } \\
\text { doméstico - } \\
\text { percentual }\end{array}$ & $\begin{array}{c}\text { N. de quesitos } \\
\text { com resultado } \\
\text { similar ao } \\
\text { preconizado } \\
\text { pelo SIDH - } \\
\text { percentual }\end{array}$ & $\begin{array}{c}\text { N. de quesitos } \\
\text { com resultado } \\
\text { diverso ao } \\
\text { preconizado } \\
\text { pelo SIDH - } \\
\text { percentual }\end{array}$ & $\begin{array}{c}\text { N. de quesitos } \\
\text { prejudicadas } \\
\text { - percentual }\end{array}$ \\
\hline $\begin{array}{l}\text { Deslocamento } \\
\text { forçado }\end{array}$ & $210-100 \%$ & $0-0,00 \%$ & $42-20,00 \%$ & $168-80,00 \%$ \\
\hline Gênero & $540-100 \%$ & $40-7,40 \%$ & $121-22,40 \%$ & $379-70,18 \%$ \\
\hline $\begin{array}{l}\text { Criança e } \\
\text { Adolescente }\end{array}$ & $840-100 \%$ & $21-2,50 \%$ & $66-7,85 \%$ & $753-89,64 \%$ \\
\hline $\begin{array}{l}\text { Controle de } \\
\text { Convencionalidade }\end{array}$ & $90-100 \%$ & $10-11,11 \%$ & $40-44,44 \%$ & $40-50,0 \%$ \\
\hline Liberdade Pessoal & $150-100 \%$ & $73-48,66 \%$ & $77-51,33 \%$ & $0-0,00 \%$ \\
\hline $\begin{array}{l}\text { Liberdade de } \\
\text { Expressão }\end{array}$ & $720-100 \%$ & $114-15,83 \%$ & $42-5,83 \%$ & $564-78,33 \%$ \\
\hline $\begin{array}{l}\text { Resultado total da } \\
\text { pesquisa }\end{array}$ & $2540-100 \%$ & $258-10,11 \%$ & $388-15,21 \%$ & $1904-$ \\
\hline
\end{tabular}

Fonte: Adaptado de (BRASIL, 2015).

Diante do panorama apresentado, mesclando-se os dados colhidos da pesquisa empírica feita em cada um dos itens e subitens examinados, observa-se que a maior parte dos itens analisados (quase $75 \%$ deles), buscados nos julgados do TJPR e comparados com os entendimentos da Corte IDH, não pode ser analisada efetivamente, tendo em vista a ocorrência de "distinguishing", por haver portanto dessemelhança relevante entre os casos do TJPR e os referenciais paradigmas da Corte IDH. O fato de não haver coincidência dos fatos jurídicos que embasam os julgados compromete também, ne essariamente, a sua "ratio decidendi", que se constitui no(s) 
fundamento(s) jurídico(s) - as razões de decidir - que sustentam cada uma das questões levantadas nos julgados (DIDIER JUNIOR, 2013). Assim, em 1904 pontos, não foi possível a análise de mérito, restando-os prejudicados.

Foram examinados, com efeito, 636 tópicos, apresentando 388 deles interpretação discrepante com os precedentes da Corte IDH. Já em 258 cláusulas, viu-se interpretação harmônica com o que preceitua o Tribunal Internacional. Ou seja: mesmo não tendo sido utilizada interpretação de tratado internacional nestes 258 pontos, o resultado a que chegou o TJPR seria similar ao que teria adotado a Corte IDH, caso estivesse a apreciar a questão.

Assim, em números válidos - excluindo-se os pontos prejudicados -, em 60,06\% dos pontos houve interpretação com resultados diversos da Corte IDH; somente em 39,93\% dos pontos houve interpretação que chegaria a resultados similares.

Admitindo-se que o resultado geral dos pontos pode não ser o mais fidedigno, uma vez que nele se concedeu maior pontuação entre os seis assuntos estudados àqueles que foram mais vezes analisados, seja pelo fato de terem subitens, seja por terem sido analisados em número maior de enunciados da Corte IDH, mostra-se interessante compor outro modelo de avaliação dos dados: somarem-se os percentuais de cada um dos temas, considerando-os com mesmo peso, e dividi-los por seis. A Tabela 23 resume os percentuais a partir dos temas e critérios analisados.

Tabela 23: Avaliação dos dados

\begin{tabular}{lcccc}
\hline Temas principais & $\begin{array}{c}\text { N. total de } \\
\text { quesitos com } \\
\text { fundamentação } \\
\text { de direito } \\
\text { doméstico - } \\
\text { percentual }\end{array}$ & $\begin{array}{c}\text { N. de quesitos } \\
\text { com resultado } \\
\text { similar ao } \\
\text { preconizado } \\
\text { pelo SIDH - } \\
\text { percentual }\end{array}$ & $\begin{array}{c}\text { N. de quesitos } \\
\text { com resultado } \\
\text { diverso ao } \\
\text { preconizado } \\
\text { pelo SIDH - } \\
\text { percentual }\end{array}$ & $\begin{array}{c}\text { N. de quesitos } \\
\text { prejudicadas } \\
\text { - percentual }\end{array}$ \\
\hline $\begin{array}{l}\text { Deslocamento } \\
\text { forçado }\end{array}$ & $100 \%$ & $0,00 \%$ & $20,00 \%$ & $80,00 \%$ \\
\hline Gênero & $100 \%$ & $7,40 \%$ & $22,40 \%$ & $70,18 \%$ \\
\hline $\begin{array}{l}\text { Criança e } \\
\text { Adolescente }\end{array}$ & $100 \%$ & $2,50 \%$ & $7,85 \%$ & $89,64 \%$ \\
\hline $\begin{array}{l}\text { Controle de } \\
\text { Convencionalidade }\end{array}$ & $100 \%$ & $11,11 \%$ & $44,44 \%$ & $50,0 \%$ \\
\hline Liberdade Pessoal & $100 \%$ & $48,66 \%$ & $51,33 \%$ & $0,00 \%$ \\
\hline $\begin{array}{l}\text { Liberdade de } \\
\text { Expressão }\end{array}$ & $100 \%$ & $15,83 \%$ & $5,83 \%$ & $78,33 \%$ \\
\hline $\begin{array}{l}\text { Resultado total da } \\
\text { pesquisa }\end{array}$ & $100 \%$ & $14,25 \%$ & $25,31 \%$ & $61,36 \%$ \\
\hline
\end{tabular}

Fonte: Adaptado de (BRASIL, 2015).

Com este cálculo, igualando-se a importância de cada um dos seis temas pesquisados, verifica-se que ampliou-se o percentual de julgados do TJPR nos quais não se acompanhou, mesmo que tacitamente, a jurisprudência da Corte IDH. Em porcentagem de pontos válidos ${ }^{14}$, a pesquisa

\footnotetext{
${ }^{14}$ Considerando-se apenas os comparativos que efetivamente puderam ser traçados, cujas decisões versaram sobre fatos parecidos.
} 
demonstrou que em 63,97\% o TJPR não atendeu os precedentes da Corte IDH, enquanto em $36,02 \%$ respeitou-os implicitamente.

Portanto, tendo como pano de fundo os números em apreço, não é demais induzir que, diante dos casos analisados, notadamente à luz das questões jurídicas vistas em cada uma das decisões, o TJPR não vinha observando, pelo menos até 2015, os "standarts" preconizados pela Corte IDH, porquanto em quase $100 \%$ dos casos, mesmo cuidando de matérias comuns à jurisprudência da Corte IDH - matérias disciplinadas pelo DIDH -, o TJPR deixou de enfrentar, explicitamente, qualquer argumento de ordem internacional. Nos casos em que não abordou o direito internacional para resolução dos conflitos, a maior parcela dos julgados adotou posições substancialmente diferentes das reconhecidas pela Corte IDH. A contrário sensu, observa-se que a observância por parte do TJPR das manifestações do SIDH teria o poder de possivelmente alterar o sentido da maior parte de suas decisões.

O silêncio (ou a ignorância) do SIDH revelada na quase totalidade dos acórdãos em matéria de DIDH proferidos no TJPR pode revelar o desprestígio do SIDH pelo julgadores, o seu desconhecimento em relação às decisões daquela Corte, ou, talvez até, a prepotência com que, via de regra, órgãos judiciais tratam a si mesmos, como se isolados de um sistema maior. Restou evidente que na maior parte dos julgados se ignorou por completo a coexistência de sistema jurídico doméstico com o sistema interamericano ao qual o Brasil, por força de documentos internacionais, está vinculado. Igualmente, em alguns casos em que foi instado a se manifestar sobre o SIDH, deixou evidente o TJPR que não considera vinculantes os precedentes da Corte IDH.

Do universo total de decisões pesquisas, aqui consideradas de modo fatiado, acompanhando cada um dos enunciados extraídos da jurisprudência da Corte IDH, foi possível perceber que em quase dois terços delas o TJPR tem decidido de modo contrário ao que teria julgado o SIDH, não levando em conta o que este tem a dizer ao sistema de justiça doméstico.

\section{CONCLUSÃO}

No início da pesquisa a hipótese prevalente era a de que as decisões da Corte IDH reverberavam pouco nas decisões do TJPR em matéria de DIDH, uma impressão que se estende aos demais órgãos do sistema de justiça brasileiro. Em um estudo bibliográfico os autores certamente não encontrariam dificuldades em "confirmar" essas hipóteses. A pesquisa empírica, contudo, traz conclusões muito mais contundentes. Após quase 10 anos de reconhecimento supralegalidade dos tratados internacionais de Direitos Humanos, bem como diante de grandes e hercúleos esforços, mais ou menos retóricos, dos últimos governos brasileiros em priorizar o diálogo e valorizar o SIDH, o Poder Judiciário brasileiro, na pesquisa exemplificado pelo TJPR, ainda o ignora por completo. Com efeito, nos 373 acórdãos, em que foram analisados 2550 itens relativos a Direitos Humanos, em apenas 10 casos foi possível identificar nas decisões alguma menção direta a tratados internacionais do SIDH. Nos demais casos, além de não citar os documentos interamericanos, o TJPR não acatou, mesmo que implicitamente, os parâmetros protetivos delineados pelo SIDH, notadamente pela Corte IDH.

A pesquisa indica de forma clara e inequívoca que, sem temor de exagerar, são nulas as tentativas por parte do TJPR de estabelecer diálogos com o SIDH, mantendo-se a Corte paranaense sobremodo alheia aos debates travados no âmbito da OEA.

A recíproca, contudo, não é verdadeira. O SIDH, por ocasião dos julgamentos dos casos Arlei Escher (OEA, 2015) e Sétimo Garibaldi (OEA, 2015), ambos oriundos do judiciário paranaense e que chegaram à apreciação do SIDH, levaram em consideração em suas decisões as 
manifestações de todos os atores jurídicos domésticos que de alguma maneira atuaram nos episódios.

Nesse contexto, de completo desconhecimento, a hipótese de que o diálogo era falho e que seria necessário ampliá-lo mostrou-se por demais otimista. Não há diálogo porque, antes dele, não há sequer o reconhecimento do SIDH. Muitas podem ser as consequências dessa ausência de diálogo, mas não há como ignorar-se um déficit de jurisdição internacional, visto que a maior parte dos cidadãos brasileiros, geralmente das camadas mais hipossuficientes, têm recebido prestações jurisdicionais de segunda categoria - influenciada por debates locais e, por vezes, eivados de pressões de poderosos locais -, em desacordo com os debates mais profícuos e produtivos na seara dos direitos fundamentais/humanos.

Todos são responsáveis pelos direitos humanos, mas os juízes - mormente os integrantes do sistema estadual de justiça - detêm uma posição privilegiada e não podem eximir-se dessa responsabilidade de fazer valer as normas mais importantes do ordenamento jurídico brasileiro, inscritas com letras de ouro na Constituição da República e nos tratados internacionais de direitos humanos.

A doença está diagnosticada. Cabe, agora, encontrarem-se remédios e caminhos adequados para solucionar as deficiências e carências apontadas, tarefa por demais extensa e que foge aos estreitos limites deste trabalho.

\section{REFERÊNCIAS}

ALCALÁ, Humberto Nogueira. Dignidad de la persona, derechos fundamentales y bloque constitucional de derechos: una aproximación desde Chile y América Latina. Revista de Derecho da Universidad Católica del Uruguay, v. 1, n. 10, p. 131, 2010.

ALCALÁ, Humberto Nogueira. Diálogo interjurisdiccional, control de convencionalidad entre los tribunales nacionales y la Corte Interamericana de Derechos Humanos en Chile. Estudios Constitucionales, año 10, n. 2, p. 57-140, 2012.

BRASIL. Supremo Tribunal Federal. Acórdão no Recurso Extraordinário n. 466.343-1. Tribunal Pleno. Relator: Peluso, Cezar. Brasília, 5 jun. 2009. Lex: Jurisprudência do STJ e Tribunais Regionais Federais, Brasília, 05 jun. 2009.

BRASIL. Supremo Tribunal Federal. Tribunal de Justiça. Acórdão em "Habeas Corpus" n. 518530-8. Relator: Francisco Cardozo Oliveira. Tribunal de Justiça do Estado do Paraná, Curitiba, 12 fev. 2009. Lex: Jurisprudência do Tribunal de Justiça do Estado do Paraná, Curitiba, 06 mar. 2009. Disponível em

<https://portal.tjpr.jus.br/jurisprudencia/j/1778347/Ac\%C3\%B3rd\%C3\%A3o-518530-8>. Acesso em: 7 nov. 2015.

BRASIL. Supremo Tribunal Federal. Tribunal de Justiça do Estado do Paraná. Pesquisa jurisprudências. 2015. Disponível em:

<https://portal.tjpr.jus.br/jurisprudencia/publico/pesquisa.do?actionType=pesquisar $>$.Acesso em: 05 ago. 2015. 
EPSTEIN, Lee; KING, Gary. Pesquisa empírica em direito: as regras de inferência. São Paulo: Direito GV, 2013.

KAZMIER, Leonard J. Estatística aplicada à economia e administração. São Paulo: Pearson Makron Books, 1982. (Coleção Schaum)

KITCHENHAM, Barbara. Procedures for performing systematic reviews: Technical report TR/SE-0401. Austrália: Department of Computer Science, Keele University and National ICT, 2004.

ORGANIZAÇÃO DOS ESTADOS AMERICANOS. Comissão Interamericana de Direitos Humanos. 2015. Disponível em: 〈http://www.oas.org/pt/cidh/>. Acesso em: 30 nov. 2015.

ORGANIZAÇÃO DOS ESTADOS AMERICANOS. Corte Interamericana de Direitos Humanos. Livros publicados pela Corte IDH. 2015. Disponível em:

<http://www.corteidh.or.cr/index.php/es/todos-los-libros>. Acesso em: 12 nov. 2015.

RAMOS, André de Carvalho. Responsabilidade internacional do Estado por violação de direitos humanos. Revista do Conselho da Justiça Federal, Brasília, n. 29, p. 53-63, abr./jun., 2005. Disponível em: <http://www.jf.jus.br/ojs2/index.php/revcej/issue/view/44>. Acesso em: 13 out. 2015.

RAMOS, André de Carvalho. Mandados de criminalização no direito internacional dos direitos humanos: novos paradigmas da proteção às vítimas de violações de direitos humanos. Revista Brasileira de Ciências Criminais, São Paulo, v. 62, p. 9, 2006.

RAMOS, André de Carvalho. A relação entre o Direito Internacional e o Direito Interno no contexto da pluralidade das ordens jurídicas. Anuário Brasileiro de Direito Internacional, Belo Horizonte, v. 1, n. 12, p. 67-94, 2012.

RICHARDSON, Roberto Jarry et al. Pesquisa Social: métodos e técnicas. São Paulo: Atlas, 1999.

SPIEGEL, Murray. Probabilidade e Estatística. São Paulo: McGraw Hill do Brasil, 1978. (Coleção Schaum)

SUDRE, Frédéric. “A propôs du 'dialogue de juges' et du controle de conventionnalite”. Paris: Pedone, 2004.

TRIBUNAL DE JUSTIÇA DO ESTADO DO PARANÁ. Pesquisa jurisprudências. 2015. Disponível em:

<https://portal.tjpr.jus.br/jurisprudencia/publico/pesquisa.do?actionType=pesquisar $>$. Acesso em: 15 ago. 2015. 